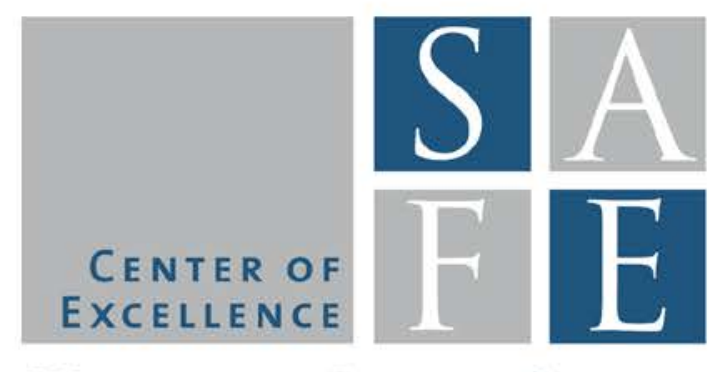

WORKING PAPER SERIES

Markku Kaustia - Samuli Knüpfer - Sami Torstila

\title{
Stock Ownership and Political Behavior: Evidence from Demutualization
}

SAFE Working Paper Series No. 2 


\title{
Stock Ownership and Political Behavior: Evidence from Demutualizations*
}

\author{
Markku Kaustia \\ Aalto University \\ Samuli Knüpfer \\ London Business School \\ Sami Torstila \\ Aalto University
}

February 26, 2013

\begin{abstract}
A natural experiment in which customer-owned mutual companies converted to publicly listed firms created a plausibly exogenous shock to the stock market participation status of tens of thousands of people. We find the shock changed the way people vote in the affected areas, with a $10 \%$ increase in share-ownership rate being followed by a $1.3 \%-3.1 \%$ increase in right-of-center vote share. The institutional details and additional tests suggest that wealth, liquidity, and taxrelated incentives cannot fully explain the results. A plausible explanation is that the associated increase in the salience of stock ownership causes a shift in voters' attention.
\end{abstract}

Keywords: Stock market participation, political behavior, salience, attention JEL classification: D72, G11, P16

\footnotetext{
*Emails: markku.kaustia@aalto.fi, sknupfer@london.edu, sami.torstila@aalto.fi. We thank Reena Aggarwal, Stefano DellaVigna, Brandon Julio, Jeremy Page, Christopher Parsons, Matti Sarvimäki, Henri Servaes, Paolo Volpin, Ernst-Ludwig von Thadden, Jeffrey Wurgler, conference participants at the Western Finance Association 2012 meeting, the Florida State University SunTrust Beach Conference 2012, the organizers of the American Political Science Association 2012 meeting, as well as seminar participants at Aalto University, Goethe University Frankfurt (House of Finance), Norwegian School of Economics, Oxford University, and University of Amsterdam. Parts of this work were completed while Kaustia was at Ross School of Business, University of Michigan, and Torstila at Haas School of Business, University of California Berkeley. The authors acknowledge financial support from the Academy of Finland.
} 


\section{Introduction}

A voluminous literature studies what makes individuals own and trade different types of financial instruments (for reviews, see Guiso, Haliassos, and Jappelli, 2003; Campbell, 2006; Curcuru et al., 2010; and Barber and Odean, 2012). Less studied in the literature is the idea that the asset holdings themselves may also influence individuals' behavior. In this paper, we analyze this question in a domain with potentially far-reaching consequences on society. Specifically, we analyze how people's stock market participation status affects their voting decisions in parliamentary elections. Portfolio heterogeneity can lead to different levels of wealth accumulation. Theory suggests that wealthier owners, in turn, shift their voting toward marketoriented policies that protect their wealth (DiPasquale and Glaeser, 1999; Biais and Perotti, 2002; Dietz and Haurin, 2003; Pagano and Volpin, 2005 and 2006; Perotti and von Thadden, 2006).

The idea that ownership affects behavior is not new: Engels (1873) proclaimed that "the worker who owns a little house to the value of one thousand thalers is certainly no longer a proletarian..." The presumption that investing in stocks influences people was also underlying the New York Stock Exchange's campaign to promote the stock market in the 1950s (Traflet, 2003). More recently, political commentators saw President Bush’s Ownership Society initiative as a strategy for crafting an "investor class" that was expected to lock in millions of votes (Nadler, 2000; Barnes, 2004). ${ }^{1}$ These policies toward increasing ownership could influence

\footnotetext{
${ }^{1}$ Other government initiatives targeted at increasing ownership are widespread, including programs for privatizing state ownership in 59 countries (Jones et al., 1999). These programs often involve retail investor incentives intended to attract a large stockholder base (Keloharju, Knüpfer, and Torstila, 2008). Bortolotti, Fantini, and Siniscalco (2001) show right-of-center governments are more likely to privatize state-owned companies, possibly in an attempt to gain new voters.
} 
voting by providing stronger incentive for better property rights and lower capital gains and dividend taxes, in the spirit of classical models of political economy.

Together with these incentives, new stockholders also have an incentive to become informed about the stock market and the economy. This incentive can alter their information acquisition, and to the extent that it also promotes interest in societal issues at large, could make stockholders more likely to vote in national elections. This shift in attention can increase sympathy for freemarket-oriented right-of-center policy by causing people to interpret issues through the lens of an investor. $^{2}$ We bundle these attention-related channels under what we call stock ownership salience.

An ideal experiment on the effect of stock ownership on voting behavior would involve a random assignment of shares to a group of individuals and a control group of otherwise identical individuals. An analysis of the stock ownership salience effect would also require an exchange of an existing asset for a listed stock, with other economic factors, such as wealth, held constant. Cross-sectional analyses not involving such exogenous shocks do not allow the identification of a causal effect, as omitted variables are likely to simultaneously determine financial circumstances and the behavioral outcomes of interest.

Our empirical setting comes reasonably close to the ideals outlined above. The identification strategy exploits a series of plausibly exogenous shocks to the stock market participation status of a large group of people. These shocks originate from conversions of mutually held regional

\footnotetext{
${ }^{2}$ Mullainathan (2002) develops a model of human memory in which even uninformative signals influence beliefs if they affect what people recall. In Mullainathan, Schwartzstein, and Shleifer (2008), a key strategy adopted by a persuader is to influence the lens through which the decision-maker views the attributes of an object. Goidel, Shields, and Peffley (1997) and DellaVigna and Kaplan (2007) provide evidence of media exposure affecting voting decisions. A large literature in political science under the term "agenda-setting" discusses how the framing of information can affect the electorate (McCombs and Shaw, 1972; Iyengar and Kinder, 1987; Edwards, Mitchell, and Welch, 1995; Weaver, McCombs, and Shaw, 2004).
} 
telecommunications firms into publicly listed companies in Finland in the 1990s. ${ }^{3}$ Prior to the demutualizations, there were 17 mutuals, and three of them chose to demutualize. The demutualizing firms covered $20 \%$ of the country and serviced over 400,000 customer-owners who would obtain shares in a newly listed public corporation that would continue the operations of the old mutual. For about 120,000 individuals who did not previously hold any publicly listed stock, these events represented a shock to their stock market participation status holding paper wealth constant. ${ }^{4}$ The process did not entail a transfer of property rights - the owners, as well as the assets they owned, stayed the same. These features of the demutualizations make the setting unique and allow us to identify the effect of a geographically clustered change in the type of asset ownership on voting behavior.

The ownership data we use are the official records of title and are therefore of very high quality as well as free of biases associated with survey data. We merge the ownership data with similarly reliable election results at the zip-code level, as well as a large set of demographic and socioeconomic variables including wealth, income, education, homeownership, age cohort shares, and population density. That these data originate from official government registers means they are comprehensive, reliable, and do not suffer from measurement error problems associated with survey-based data sets. These rich data also allow us to rule out the usual suspects that can plague natural experiments of a similar type-the results do not seem to be

\footnotetext{
${ }^{3}$ Demutualizations are not exceedingly rare. For example, one third of the US mutual life insurance companies demutualized between 1995 and 2004 (Erhemjamts and Leverty, 2010). Unfortunately, detailed ownership data is not available in those cases.

${ }^{4}$ We explicitly control for changes in wealth caused by the stock price fluctuation during the sample period. In theory, the mutual form could be less valuable if the bundling of customer and stockholder roles leads to inefficient risk-sharing (Fama and Jensen, 1983), or if the absence of a threat of outside takeover makes managers more likely to extract private benefits (Lamm-Tennant and Starks, 1993). On the other hand, Mayers and Smith (1986) show empirical evidence suggesting benefits to a mutual form. The publicly listed stock is also more liquid, which can increase its value. We analyze the issue of liquidity in detail in the last section of the paper.
} 
driven by systematic differences between the treatment and control areas, other violations of the exclusion restriction, or a weak instrument.

Our main analysis utilizes the demutualizations in a two-stage panel regression in which right-of-center vote share is explained with instrumented share ownership. The instrument, an indicator for a zip code having experienced a demutualization, does not suffer from the weak instrument problem as the demutualizations cause a substantial increase in stock market participation. Share-ownership rates in the treatment towns are $49 \%$ to $71 \%$ higher over the long term, relative to other towns, conditional on a large set of control variables, as well as zip-code and election fixed effects.

The results show instrumented share ownership is positively and significantly associated with right-of-center voting. Our preferred (and most conservative) estimate suggests a 10\% increase in the stock market participation rate translates into a $1.3 \%$ increase in the vote share of the main right-of-center party ( $t$-value 2.1). Different definitions of the dependent variable, subsamples, and control variables generally produce larger and more significant estimates. We put together several pieces of evidence that collectively speak against violations of the exclusion restrictionthe assumption that the demutualizations did not have an impact on voting through any channels other than stock market participation. We first note that our fixed effects panel regressions control for many observable characteristics and any time-invariant unobservables. For example, the demutualizing areas are more urban than other areas, which is captured by the zip-code fixed effects and a variable measuring population density.

In addition, we employ matching estimation using the same large set of observable covariates and additionally including the pre-treatment right-of-center vote level and vote trend as matching variables. These analyses help in addressing the exclusion restriction in the following way. The 
process of demutualization itself could have been endogenously triggered by an omitted variable that had an influence on right-of-center voting independent of share ownership. For example, underlying differences in the support for free markets and the beneficial role of the stock market might have played a role in the acceptability of the demutualization (although the formal decision to demutualize was made by the company general meeting without any obvious political motives). Towns that demutualized might also have been independently becoming more right-ofcenter prior to the demutualization. We capture the right-of-center vote levels and trends by voting data in the four-year period preceding the start of the sample period. We use these pretreatment vote variables in matching estimation: the analysis compares demutualizing towns to areas that did not demutualize but had similar characteristics, as well as similar pre-treatment voting levels and trends. Matching by trend has the additional benefit of controlling for the possibility that areas differ in terms of their sensitivity to national patterns of right-wing support, as a treatment area is compared to a control area with a similar pre-treatment electoral swing pattern. The results from adding pre-treatment levels and trends do little to change the conjecture that the demutualization events were plausibly exogenous conditional on observables.

We investigate and document two further issues related to the mechanism of the influence on voting. First, we analyze whether the increase in right-of-center vote share is due solely to shifts in party choice or whether it is caused partly by changes in voter turnout patterns. Employing two-stage regressions similar to those used for identifying the impact of ownership on vote shares, we find some evidence that share ownership increases voter turnout. Our analysis suggests, however, that changes in turnout may only be a partial explanation for the shift to the right and that some of the effect is due to shifts in party choice. 
Second, the unique features of the setting as well as results of additional analyses allow us to consider several alternative explanations for the observed voting patterns. Recall that the process of demutualization into the corporate form does not entail a transfer of property rights-the owners, as well as the assets they own, stay the same. The rich data also allow us to explicitly control for wealth. Furthermore, we find the extent to which people sold their shares after a demutualization in an area is not reliably related to future voting patterns. These results suggest an increase in wealth and in its liquidity are not driving the effect. To a small extent, the change in corporate form increased incentives to favor a lower tax policy. This effect, however, appears to be small (an additional gain of about 60 cents per year from a one percentage point decrease in the tax rate). Policy uncertainty lowers the expected value of the benefit even further. The features of the setting, the additional analyses, and the small tax effects suggest the results cannot be fully explained by wealth and tax channels. A potential explanation is stock ownership salience that can influence voting either directly or by amplifying the effect of any perceived changes in direct economic incentives in the voter's mind.

In addition to the literature on political economy and persuasion discussed earlier, our paper relates to recent work on politics and portfolio choice. Empirical studies on portfolio choice show that political preferences are strongly related to the stock market participation decision (Kaustia and Torstila, 2011) as well as the industry tilt in stock portfolios (Hong and Kostovetsky, 2012). Bonaparte and Kumar (2013) find that politically active individuals, regardless of their political affiliation, are more likely to participate in the stock market. Our paper also shares a theme with papers that investigate the impact of exogenous shocks on individuals’ beliefs. Di Tella, Galiani, and Schargrotsky (2007) find that Buenos Aires squatters who were given land titles developed more individualist and materialist beliefs while DellaVigna 
and Kaplan (2007) document that the introduction of the Fox News Channel increased Republican voting in the affected areas.

The outline of the remainder of the paper is as follows. Section 2 introduces data sources and discusses the institutional details of the demutualizations. Section 3 develops the identification strategy. Section 4 presents the main results from panel regressions, and section 5 includes extensions and robustness checks. Section 6 discusses mechanisms, and section 7 concludes.

\section{Data and institutions}

Our dataset includes comprehensive information aggregated at the zip-code level on (a) results in Finnish parliamentary elections, (b) ownership of shares in the area, and (c) a large number of demographic and socioeconomic characteristics. The number of zip codes is about 2,500, and we have data from the 1991, 1995, 1999, and 2003 elections.

\section{A. Elections}

Elections for the 200-seat Finnish Parliament are held every four years. No other elections that could introduce biases, such as referenda, take place on the election day. Finland uses the d’Hondt constituency list system, typical of multiparty proportional representation systems. The number of parliamentary seats each party receives is proportionally determined by party-level vote totals in each of 15 regional constituencies. This voting system presents advantages for our analysis in comparison with a two-party, district-based majority voting system. First, as results count towards total party representation, voting behavior is less likely to be biased by strategic voting for a non-first-choice candidate seen as more electorally viable. Second, as each constituency offers a choice between hundreds of candidates, party-level election results contain 
less noise generated by variation in the vote-getting ability of individual candidates. For further details of the electoral process and results, see Nurmi and Nurmi (2004).

The election data come from Statistics Finland, the official governmental statistics agency. We obtain the number and distribution of ballots cast on election day for each voting precinct. The data also include the number of voting-aged (18 on or before the election date) inhabitants in each voting precinct as of January 1 of the election year.

The voting data for 1991 through 1999 include the votes cast on election day (a Sunday). The voters also have the alternative to vote through a postal ballot system before the election. The 2003 postal votes are allocated to the precinct level, which allows us to work with the regional distribution of all votes. For 1991 through 1999, we are able to analyze only the election-day votes. However, the correlation between party vote shares in the postal votes and election-day votes is very high.

In some cases, a voting precinct can cover several zip codes. However, the vast majority of the population in a particular voting precinct usually resides in a single zip-code area. We match each precinct to a zip code following the procedure in Kaustia and Torstila (2011).

\section{B. Share ownership}

The Finnish Central Securities Depository maintains records of stock directly held by all individuals in practically all listed companies in Finland. Our ownership data cover the period from January 1995 to November 2002. For a detailed description of the FCSD data, see, for example, Grinblatt and Keloharju (2000).

Based on these data, we calculate the number of stock market investors in each zip code at the time of the parliamentary elections. During the study period, elections took place in 1995 and 1999. The 2003 elections took place four months after the coverage of our stock ownership data 
ends. The ownership data from November 2002 serve as a proxy for the ownership at the time of the elections in March 2003.

In determining the local number of stock market participants, we count all those individuals who have common stock in their account at the time of the election, and divide that number by the total number of inhabitants in the zip code. Although the reason for this definition is ultimately imposed by data considerations, we note the direct share holdings are by far the most important means of participating in the stock market in Finland. During the sample period, no personal retirement accounts existed in Finland and mutual funds were a relatively new phenomenon. Kaustia and Knüpfer (2012) provide a more detailed discussion of these issues.

\section{Demographic and socioeconomic controls}

Statistics Finland provides a number of demographic and socioeconomic zip-code-level variables for the years 1991 through 2003. These data originate from registers maintained by the government and are practically free from the usual measurement error problems present in survey-based data sets (such as the US Census). For 1991, we only have the total number of inhabitants by zip code. For 1995 through 2003, we have the proportion of people in various age cohorts, median income, mean wealth, level of education, unemployment rate, proportion of owner occupied dwellings, population density, and proportion of females.

Although using the exact timing of the elections in the analyses would be tempting, we choose not to do so, because some of our control variables for 1999 are only available at the end of year 1999 when all the demutualizations had taken place. We use data from 1995 and 2003 instead in a two-period panel regression. Collapsing the time series into pre- and postdemutualization states has the further benefit of mitigating the issue of inflated $t$-values in a 
panel with many observations per each cross-sectional unit (see Bertrand, Duflo, and Mullainathan, 2004).

We have 2,753 total zip codes before excluding 22 located in the autonomous island province of Åland, where the major parties do not set candidates. We further eliminate 121 zip codes with undefined geographical boundaries, boundary changes between the elections, or no information on the number of inhabitants available. After merging these zip codes with the ownership data, we have 2,610 zip codes. In the regressions, we further require that each of the three major parties have received at least one vote, that the zip code has all the control variables available, and that the dependent variable does not fall outside its 1st and 99th percentiles (the results are robust to relaxing this last requirement). This procedure gives a final sample size of about 2,300 zip codes each year.

\section{Demutualizations}

Telecom services in Finland are provided in a decentralized manner by a number of local telecom firms, as well as one partially government-owned company. In the early 1990s, none of these firms were publicly listed.

To obtain a landline telephone, a prospective customer would have to acquire a certificate of participation in the local mutual company. The mutuals issued the certificates and acted as market makers. The certificates were transferable, so a private individual could sell one to another due to, for example, relocating outside the service area. One could also commonly find certificates in estate auctions.

In the late 1990s, some of the local telecom companies had expanded into new businesses, such as providing wireless services, and some of them started investigating the possibility to convert into a publicly listed firm. Three firms, which operated in areas that cover about 400 zip 
codes, chose to go ahead with the conversion. From the viewpoint of the customer certificate holders, the demutualization events were plausibly exogenous to voting behavior, a position we elaborate in the following section 3.

The main features of these conversions are as follows:

- The firms were Tampereen Puhelin (TP), Keski-Suomen Puhelin (KSP), and Helsingin Puhelin (HP). Figure 1 shows the zip codes covered by these firms on a map of Southern Finland. The shares were listed on March 17, 1998, September 28, 1998, and July 1, 1999, respectively.

- The 1999 parliamentary elections were held on March 21, so two of the conversions took place before the 1999 election day and one between the 1999 and 2003 elections.

- The number of listed shares obtained with one mutual certificate was fixed and did not depend on customer type or telephone usage. Some individuals and companies had several certificates.

- The market values of shares obtained from the conversion of one certificate were 3,088 euros, 2,145 euros, and 262 euros for HP, TP, and KSP, respectively, at the close of the listing day. The differences in the values reflect differences in both the market values of the firms and the number of certificate holders that divide the market value. Any sale of the certificate or a subsequent sale of the stock was subject to capital gains taxation at a rate of 25\% until 2000 after which the rate rose to 29\% up until 2006. 
- The vast majority of the recipients did not sell the shares. Selling rate estimates imply that about $75 \%-85 \%$ of the recipients still held their shares after three years of the demutualizations.

\section{How the demutualizations solve the identification problem}

Our identification strategy relies on the idea that the demutualizations generated ownership changes that in many respects resemble randomized, and exogenous, shocks from the viewpoint of the individuals receiving the shares. Individuals in the demutualizing towns serve as the treatment group, whereas all other individuals belong to the control group. The benefit of this research design is that it can, under certain assumptions, address the causality of ownership on voting behavior. Below we present our identification strategy, and then address potential endogeneity concerns.

\section{A. Regressions}

Before presenting the models we use, it is instructive to consider a simple panel regression that attempts to document the influence of share ownership on voting behavior. The model explains the right-of-center vote share with share ownership:

$$
c_{i t}=\alpha p_{i t}+e_{i t},
$$

where $i$ and $t$ index zip codes and elections, $c_{i t}$ is the right-of-center vote share, $p_{i t}$ is the share-ownership rate, and $e_{i t}$ is the error term (the intercept is omitted from the formulas but is included in all the models). Unobserved heterogeneity makes the estimation of $\alpha$ challenging. The omission of observable and unobservable characteristics that jointly determine ownership and voting behavior is likely to bias the estimate in a way that is not known a priori. 
The first step to control for omitted variables is to include all the relevant observable variables and control for zip-code and election fixed effects. Such a model is

$$
c_{i t}=\alpha p_{i t}+\beta \mathbf{X}_{\mathrm{it}}+u_{i}+v_{t}+e_{i t},
$$

where $c_{i t}$ is the right-of-center vote share, $p_{i t}$ is the share-ownership rate, $\mathbf{X}_{\mathbf{i t}}$ is a vector of observable characteristics, $u_{i}$ and $v_{t}$ are zip-code and election fixed effects, and $e_{i t}$ is the error term.

Natural candidates for observables $\mathbf{X}_{\mathbf{i t}}$ are wealth, income, education, home ownership, age composition, and population density (see Guiso, Haliassos, and Jappelli, 2003, and Curcuru et al., 2010, for reviews on the determinants of stock market participation). Zip-code and election fixed effects control for time-invariant zip-code and election characteristics. A zip-code fixed effect could, for example, be due to a local media slant related to stock market sentiment or political bias, not captured by observable variables. The election-year fixed effects control for simultaneous shocks to ownership and political views, such as varying IPO activity.

Although model (2) is a significant improvement over model (1), its causal interpretation is still hampered by time-varying shocks that jointly influence ownership and voting. Here we take advantage of the ownership shocks generated by the demutualizations. We estimate the following instrumental variable regression with 2SLS:

$$
\begin{gathered}
p_{i t}=\delta \mathbf{X}_{\mathrm{it}}+\pi I_{i t}+u_{i}+v_{t}+e_{i t} \\
c_{i t}=\alpha \hat{p}_{i t}+\beta \mathbf{X}_{\mathrm{it}}+\gamma I_{i t}+g_{i}+h_{t}+f_{i t} .
\end{gathered}
$$

The first-stage regression explains share ownership by observables $\mathbf{X}_{\mathbf{i t}}$ and an indicator $I_{i t}$ taking the value of one if a zip code $i$ has experienced a demutualization in time $t$ and zero 
otherwise, and zip-code and election fixed effects. The second-stage model includes the same set of observables, the zip-code and election fixed effects $g_{i}$ and $h_{t}$, and an error term $f_{i t}$. The secondstage model (4) explains the right-of-center vote share with the instrumented ownership rate from regression (3).

The exclusion restriction of the model is the assumption that demutualizations have no direct effect on voting in addition to their impact on share ownership, conditional on the control variables. In effect, we restrict the coefficient $\gamma=0$ to capture this assumption. If the exclusion restriction holds, the 2SLS model successfully identifies the causal influence of share ownership on voting behavior.

\section{B. Potential endogeneity concerns and matching methods}

The identification rests on the assumption that the demutualization treatment did not coincide with any other change in determinants of the right-of-center vote share, conditional on the control variables of the model. The controls we include capture differences between the treatment and control areas in many plausible determinants of voting, including population density, wealth, income, education, and age composition. The variables also control for the economic motives to carry out a demutualization in particular types of areas. ${ }^{5}$ Therefore, the regression effectively compares a treatment zip code to a control zip code that is similar to the treatment area along observable characteristics. We believe this identification strategy makes significant progress in aiding a causal interpretation.

\footnotetext{
${ }^{5}$ The argument is that the demutualizations were plausibly exogenous from the viewpoint of individuals. It is still possible that a firm serving one area may be more likely to demutualize than another firm operating in another identical area, due to unobserved heterogeneity at the level of firms. While this would not be a problem in our research question, it would undoubtedly complicate the analysis of other types of questions, say, regarding the corporate finance aspects of demutualizations.
} 
In addition to making sure the conclusions are not confounded by zip code characteristics, we also take into account the possibility that the outcome itself, i.e., right-of-center voting, might have changed in response to aspects other than stock ownership. We do this by using a matching method that makes it possible to include the pre-demutualization vote trends and vote levels in the treatment and control areas as additional control variables. The inclusion of pre-treatment vote trends and levels in the matching estimation is a good remedy against three remaining endogeneity concerns.

First, if the demutualizations took place in areas that were independently becoming more right-of-center, the estimate of the impact of the demutualization would be upward biased. Relatedly, the underlying political sentiment might have made it easier to carry out a demutualization in an area with a greater right-of-center voter base.

Second, decisions to demutualize may have been influenced by politicians observing that the practice is becoming favorable with voters in certain areas. More than a decade after the events, however, no evidence or even speculation regarding political motives to demutualize has emerged, suggesting the political effects we document are largely an unintended consequence. One might still wonder if politicians influenced the demutualization decisions. The formal decision to demutualize was made by the company general meeting that had no obvious political motives and the demutualization did not need government approval. Nevertheless, political influence would not violate the exclusion restriction as long as the effect on voting came through increased share ownership. But if right-of-center politicians perceive an underlying favorable political trend in an area, and attempt to boost this further by increasing share ownership, then the estimates would overstate the causal effect of share ownership. Matching on political trends, as described above, alleviates this concern. Institutional details also make us think this 
mechanism is not plausible. Connections between firms and politicians are weak in Finland. Faccio (2006) documents that in the end of 1990s, firms with political connections represented $0.14 \%$ of market capitalization in Finland, compared to $7.7 \%$ around the world. Transparency International consistently ranks Finland as the least (or second least) corrupt country in the world.

Third, areas may differ in terms of their sensitivity to national patterns in the vote. ${ }^{6}$ Since the natural experiment coincides with a national increase in the right-wing vote, our estimates may be upward biased if the treatment areas have a propensity to produce larger electoral swings than the control areas.

All of these concerns are alleviated by the matching analysis, as it uses both the right-ofcenter vote share in the 1995 election and the 1991-1995 vote trend as matching variables. The matching analysis thus identifies the treatment effect from control areas that have the same predemutualization vote level, the same pre-demutualization vote trend, and the same control variables as the treatment areas. The results, presented in section 5 , are similar to the results obtained with the 2SLS framework.

\section{Results from panel regressions}

\section{A. Descriptive statistics}

Table 1 reports descriptive statistics of the treatment and control areas pooling data over the three elections in the sample period (1995, 1999, and 2003). Panels A and B document differences between the treatment and control towns along many dimensions. The residents in

\footnotetext{
${ }^{6}$ As an example, political analyst Nate Silver's blog (http://fivethirtyeight.blogs.nytimes.com/) refers to this tendency as elasticity and provides values for state elasticities in US presidential elections.
} 
treatment towns have higher income, better education, and the areas are more densely populated. For example, the median annual income in the treatment towns equals 16,740 euros, whereas it is only 12,010 euros in the control towns. Panel C reports logit regressions that explain an indicator for a zip code experiencing a demutualization with zip-code characteristics measured in 1995, prior to any demutualizations had taken place. The logit marginal effects confirm many of the univariate results: wealth, education, and population density are significantly correlated with demutualizations (but income, unemployment, home ownership, and the share of female inhabitants are not). The rightmost column shows that the right-of-center vote level in 1995 and the change in right-of-center vote share from 1991 to 1995 are also systematically different from other areas demutualizations. In demutualizing towns, the right-of-center party lost votes between the 1991 and 1995 elections, but the vote share in 1995 was still higher than in other towns. Our regressions and matching models will control for all of these differences.

Our main variable of interest, the vote share of the main right-of-center party, equals $22.2 \%$ and $12.7 \%$ for the treatment and control towns, respectively. The six largest parties account for $88.4 \%$ and $90.7 \%$ of the votes cast in these areas. Share-ownership rates equal $19.5 \%$ and $7.9 \%$. As these numbers are averaged over the three elections, they include any impact from the demutualizations.

Figure 2 breaks down the sample into the three elections, and plots the share-ownership rates in treatment and control areas at the time of elections. Before the conversion, the treatment towns have a participation rate that is about 5.2 percentage points higher than in the control areas. From 1995 to 1999, the participation rate increases by 5.8 and 0.8 percentage points in the treatment and control areas, respectively. Two demutualizations had taken place between these two elections, whereas one demutualization occurred between 1999 and 2003. During this period, 
share-ownership rate increased by 4.4 and 1.4 percentage points in the treatment and control areas, respectively.

Figure 3 plots the vote share of the main right-of-center party in the treatment and control towns over the sample period. The right-of-center vote share in the control areas is relatively stable over time and ranges from $11.3 \%$ to $12.6 \%$. More time variation is present in the treatment areas: from $19.5 \%$ to $24.2 \%$. This time-series variation is great enough to mask any influence of demutualization in the univariate analysis, which is not surprising unless one expects the effects to be very large. We have argued that the relatively small changes in property rights involved in the demutualizations (the same owners still own the same assets, only in different form) should not make us expect effects of such magnitude. We turn to multivariate analyses next.

\section{B. First-stage estimates}

The success of our identification strategy depends on the validity of the first-stage regression. A strong instrument should produce a large, significant, and persistent positive impact on share ownership in the treatment towns, controlling for simultaneous changes in town characteristics. In other words, the coefficient $\pi$ in model (3) should be positive and significant.

Table 2 presents results of the first-stage regressions. Our models collapse the data into two periods, 1995 and 2003, and estimate the impact of the demutualization as the change in the share-ownership rate from 1995 to 2003 between the treatment and control towns. Including multiple (e.g., annual) observations per cross-sectional unit in a regression would run the risk of producing inflated $t$-statistics, but this is less of an issue in a two-period comparison (see Bertrand, Duflo, and Mullainathan, 2004). The demutualization dummy equals one for the 2003 election in all the towns in which the demutualization took place and zero for all other 
observations. We include town and year fixed effects that control for confounding time-invariant influences.

We consider five variants of the model that include different sets of the observables $\mathbf{X}_{\mathbf{i t}}$. The simplest version is one with only the demutualization coefficient and zip-code and election fixed effects (unreported), appearing in the first column of Table 2. The next two columns add two different sets of continuous control variables: wealth, income, education, and unemployment, and these variables supplemented with home ownership, population density, and proportion of females. The two remaining columns allow for non-linear relations by breaking down each control variable into 10 decile dummies (excluding one for each variable). All the regressions also include eight unreported age-profile variables that calculate the share of inhabitants in cohorts of 10-year intervals. Variables are log transformed to reduce the influence of skewness and to give the coefficients an interpretation as elasticities. The $t$-values are robust to clustering at the zip-code level.

The bare-bones model in the first column produces a positive and highly significant coefficient on the demutualization dummy, which suggests the treatment areas showed a much larger increase in the share-ownership rate than the control areas. The coefficient value of 0.396 ( $t$-value 22.1) implies that the share-ownership rate increases $e^{0.396}-1=48.5 \%$ in the demutualization towns (the dependent variable is the log of the stock market participation rate). The richer models suggest even stronger effects: the estimates amount to a $64.9 \%-71.3 \%$ increase in the share-ownership rate. The $t$-values are equally large in all specifications, ranging from 25.8 to 27.2 .

Allowing time variation in the predictors of share ownership does not render the effect of the demutualizations insignificant. But many of the predictors are significantly related to share 
ownership. For example, wealth, education, and home ownership are positively related to share ownership.

The explanatory power of the demutualization dummy is impressive: the F-statistic ranges from 407.4 to 757.6 . These numbers clearly indicate that the null of having a weak instrument is rejected.

\section{Second-stage estimates}

The previous section showed that the demutualization dummy is a valid instrument for share ownership. In this section, we assume zip-code fixed effects and observable characteristics suffice to control for any relevant differences, including pre-treatment trends and possibly different local sensitivity to national elections. In effect, we are assuming the exclusion restriction is not violated; that is, the coefficient on the instrument $I_{i t}$ in model 4 equals zero. We implement the IV approach by running standard 2SLS regressions in which the first-stage regressions come from Table 2. We use the fitted values from these regressions in lieu of the raw share-ownership variable and adjust the standard errors for the estimation of the fitted values. The regressions employ all the same observables from the first-stage regressions and also the zip-code and election fixed effects.

Table 3 reports the results of the 2SLS regressions. Here we follow the setup in the first-stage table in which each specification adds either new control variables or allows for more flexible functional forms. The richest specification appears in the last column that includes all the control variables broken down into decile dummies, as well as variables measuring the share of each age cohort, and zip-code and election fixed effects.

Across the specifications, income and wealth positively predict right-of-center voting, whereas unemployment rate is negatively associated with right-of-center votes. The coefficient 
estimate for the instrumented share ownership starts with the value of 0.32 in the first column ( $t$ value 4.3) and ends up taking the value of 0.14 in the fullest specification (t-value 2.1). These estimates suggest a $10 \%$ increase in the share-ownership rate increases the right-of-center vote share by $1.3 \%-3.1 \%$ (the models measure both the dependent and independent variables in logs so the magnitudes are $1.1^{0.324}-1=3.1 \%$ and $1.1^{0.139}-1=1.3 \%$ ). Broader definitions of right-ofcenter voting, discussed later, produce even larger estimates. ${ }^{7}$

The economic significance of the effect appears to be meaningful. The average vote share for the main right-of-center party equaled $12.5 \%$ in the 1995 election. The treatment predicts (Table 2, specification 5) an increase of $71.3 \%$ in participation (the dependent variable in Table 2 is logged so the increase equals $\left.e^{0.538}-1\right)$. Applying this number to the low-end-estimate of the coefficient in the second stage (from Table 3, specification 5) predicts a change of $(1+0.713)^{0.139}$ $-1=0.078$, that is, a $7.8 \%$ increase in the right-of-center vote. Applied to the $12.5 \%$ base level, this amount translates into a 0.97 percentage point increase in the right-of-center vote in the mean zip code.

A 1.2 percentage point increase in the right-of-center vote share appears to be a meaningful effect, as elections are always won at the margin. One point of comparison is the result in DellaVigna and Kaplan (2007), who study the effect of the introduction of Fox News on Republican voting, and find an effect of 0.4 to 0.7 percentage points on US presidential vote shares between 1996 and 2000.

The estimates from our preferred model imply a considerable increase in right-of-center voting following an exogenous increase in share ownership. This conclusion follows from

\footnotetext{
${ }^{7}$ Panel B in Table 3 reports the simple OLS results where we do not instrument for share ownership. The shareownership variable attracts a positive and significant coefficient that is smaller in magnitude than the 2SLS estimates. This finding suggests inferences from simple OLS estimates are likely to understate the true effect.
} 
showing our instrument has enough power to potentially have a meaningful impact on voting and that the results are robust to many different specifications-even the strictest specification that allows for a non-linear relation between control variables and vote shares. In the next section, we turn to estimating the effects with matching techniques that allow us to explicitly control for pretreatment trends, in addition to the host of control variables used in the panel regression. We also discuss further robustness checks that modify the definition of the dependent variable, and discard towns that were not able to demutualize.

\section{Matching estimation and robustness checks}

This section discusses matching estimation to establish the robustness of the main results derived using the 2SLS framework. The results show that the 2SLS estimates are unlikely to be generated by plausible violations of the exclusion restriction. We then address other robustness issues using the 2SLS analysis.

\section{A. Matching estimation}

In this section, we use matching estimation in which we match the demutualizing towns (treatment areas) to control areas that have similar characteristics and pre-demutualization vote patterns. The inclusion of the vote patterns - the pre-treatment level and trend of the right-ofcenter vote share-adds an additional layer of controls vis-à-vis the 2SLS method. Specifically, the pre-treatment vote variables address the potential violations of the exclusion restriction that were outlined in Section 3.B. These include the possibility that demutualizations took place in areas that were independently becoming more right-of-center and that the right-of-center voter base in a town made it easier to carry out a demutualization. The matching method also helps to rule out the possibility that the results are driven by right-of-center politicians perceiving an 
underlying favorable political trend in a town, and trying to boost it further by increasing share ownership. Finally, the matching method helps to control for the possibility that areas differ in their sensitivity to national patterns in the vote: treatment areas which produced larger electoral swings in the pre-treatment period are compared to control areas with similar swings.

We estimate the average treatment effect—-that is, increase in right-of-center voting due to demutualizations-using the covariate matching estimator discussed in Abadie and Imbens (2006). ${ }^{8}$ Specifically, the matching method finds control towns that are the nearest neighbors for each treatment town based on observable characteristics. The choice of the nearest neighbors is governed by a match metric that measures the distance in characteristics space between the treatment observation and a potential control observation. We report results for the inverse-ofthe-variances metric (Abadie and Imbens, 2006) and the Mahalanobis metric (Rubin, 1980; Zhao, 2004). We also estimate the treatment effects correcting for the bias that stems from the inability to find a perfect match for each treatment town using the method of Abadie and Imbens (2011).

The covariates we use for matching are based on non-forward-looking information that was available in 1995, before any of the towns had demutualized. Therefore, the control towns are similar in terms of observables to the treatment areas in 1995, except they did not demutualize. The observables we use in matching include all the categorical dummy variables for the socioeconomic characteristics used in the paper thus far and also the pre-treatment level and trend in right-of-center voting. The vote level is the logged right-of-center vote share in 1995 and

\footnotetext{
${ }^{8}$ We also experiment with the familiar propensity score matching estimator (see, e.g., Heckman, Ichimura, and Todd, 1997 and 1998). It produces estimates that are statistically significant and often larger in magnitude. We prefer to err on the side of caution and report the results using the covariate matching method.
} 
the trend is the difference in logged right-of-center vote shares between the 1991 and 1995 elections.

Table 4 shows the treatment effects estimated using the nearest neighbor method. Panels A through D show the results for matching on 1, 2, 4, and 6 nearest neighbors. Columns 1 through 3 in each panel report the estimates based on the inverse-of-the-variances distance metric, the Mahalanobis distance metric, as well as the estimator that corrects for the match discrepancy bias. $^{9}$

Across all the specifications, the treatment effect is positive and statistically highly significant. The point estimate ranges from 0.092 to 0.127 and the $z$-values range from 3.6 to 5.4. Because we are using logged variables, the additional percentage increase of right-of-center voting in the affected towns amounts to $9.6 \%-13.5 \%$. The treatment effect here is somewhat larger than in the 2SLS framework where the most conservative estimate suggests a $7.8 \%$ effect (see section 4.C.).

We estimate two modified versions of the basic model that further improve matches along the two pre-treatment political variables. First, we break down the continuous right-of-center vote trend and level variables into decile dummies. Second, we match the two variables as close as possible by giving them more weight in the distance metric. The estimates from these alternative approaches always remain statistically significant and the lowest treatment effect equals $8.1 \%$.

Taken together, the matching estimates show that differences in pre-treatment vote trends or vote levels do not drive the strong relation between share ownership and political behavior. This

\footnotetext{
${ }^{9}$ Allowing for a larger number of matches increases efficiency, but tends to increase bias due to poorer overall match quality (Imbens, 2004; Imbens and Wooldridge, 2009). The bias-corrected estimator is robust to the choice of the number of matches, and corrects for the remaining match discrepancy (Abadie and Imbens, 2011).
} 
result suggests that the estimates of the 2SLS framework are not generated by the violations of the exclusion restriction outlined in Section 3.B. Furthermore, the matching framework rules out any other violation of the exclusion restriction that relates to the differential political environment in the treatment towns prior to the demutualizations.

\section{B. Alternative dependent variables}

We now return to the 2SLS model and report two additional robustness checks. The baseline model calculates the right-of-center vote share using the votes cast for the National Coalition Party, the main right-of-center party. We consider alternative ways to define the political outcome variable, as the Finnish parliamentary system involves many parties.

Panels A and B of Table 5 show how the results change if we include in our definition of right-of-center vote share the votes cast for the Center Party. Despite its name, the Center Party is clearly right-of-center in the Finnish political spectrum. Hix and Lord (1997) provide a quantitative classification of major Finnish parties on a left-right axis (1 to 10). The main rightof-center party (National Coalition) receives a score of 7.4, the Center Party is 7.0, and the main left-of-center party (Social Democrats) is 4.4. The mean among the six largest parties is 5.5. In many rural areas, the left-right spectrum runs from the Left Coalition and Social Democrats to the Center Party, whereas the National Coalition may have only a small vote share in such areas. The prominent position of the Center Party comes from its roots as the promoter of the causes of farmers.

These regressions suggest our previously reported results are lower bounds of the true effects. Effects on center vote shares in Panel A are all strongly significant and large—even more so than the impact on National Coalition vote shares. Panel B sums the Center Party and 
National Coalition vote shares and yields estimates that are comparable to those obtained in the baseline model, but are more precisely estimated ( $t$-values range from 5.9 to 10.1).

Panel C looks at the left-of-center vote share. Consistent with the right-of-center parties gaining voters from the left, the slope estimates are negative. However, their magnitudes are smaller than the estimates for the main right-of-center party vote share. In only one specification, the $t$-value is not significant at conventional levels. The most comprehensive specification yields a coefficient estimate of -0.08 with a $t$-value of -1.98 . Perfect symmetry should not be expected, since the left-of-center share is not a linear combination of the right-of-center and center vote shares. Smaller parties are present that are more difficult to classify along the right-leftdimension. One such example is the Green Party which often promotes free-market mechanisms on issues such as labor markets, yet generally advocates tough regulation and taxation of capital markets.

Panels D and E run regressions in which the votes cast for the National Coalition and the Center parties are divided by the total votes cast for the three largest and the three medium-sized parties. The medium-sized parties are the Left Coalition, the Green League, and the Swedish People's Party. All the specifications produce a positive coefficient, and most of the estimates are statistically significant.

\section{Subsample with mutuals}

Some of the zip codes in our main dataset were not serviced by any mutual phone company in the late 1990s. Instead, these mostly rural areas were serviced by a partially governmentowned countrywide operator. To test whether this feature of the data affects the results, we drop all observations in which no mutual company existed in the first place, which leaves a subsample of mutuals that decided to demutualize versus mutuals that did not. The results are reported in 
Table 6. The point estimates for the demutualization dummy in the first stage-regression range between 0.42 and 0.52 depending on the specification, whereas the second-stage coefficients take values of $0.14-0.31$. These subsample estimates are close to the baseline results in Table 3 , with statistical significance largely unchanged.

\section{Mechanisms}

The results thus far show the demutualizations had a robust positive impact on right-of-center voting in the affected areas. In this section, we make an effort toward understanding the channels that intermediate share ownership and voting. We first analyze the extent to which the effect is due to changes in voter turnout versus vote switching. Then turning to underlying drivers, we discuss motives related to property rights, liquidity, and taxation, and finally consider the stockownership-salience hypothesis.

\section{A. Voter turnout}

An increase in the right-of-center vote share can be due to either shifts in policy preferences of existing voters or changes in the voter turnout pattern. Stock owners may, for example, be more motivated to vote than non-owners as a result of acquiring and processing more information about the economy. In this section, we analyze how stock ownership affects voter turnout.

Table 7 presents regressions corresponding to those in Table 2, but replacing the vote share with voter turnout. Voter turnout is defined as the number of votes cast divided by voting-age population. The slope estimates of the share-ownership variable are positive but small in all specifications. In the full model, a $10 \%$ increase in participation predicts a $1.1^{0.025}-1=0.24 \%$ 
increase in turnout. Statistical significance is also weaker: the full model yields a $t$-value of 0.99 , suggesting that we cannot reject the null that voter turnout was not affected. Nevertheless, it is useful to see what one would need to assume about the impact of demutualizations on voter turnout to reconcile the increase in right-of-center vote share fully with the point estimates of voter turnout. First recall the demutualization dummy predicts a $71.3 \%$ increase in stock ownership (Table 2, specification 5). Applying the predicted increase in ownership to the coefficient of turnout (Table 7, specification 5) gives $1.713^{0.025}-1=0.014$; that is, turnout is expected to increase by $1.4 \%$ in the demutualizing areas. If all of the new voters were to favor right-of-center, the 1995 mean right-of-center vote share of $12.5 \%$ would increase to $(12.5 \%+$ $1.4 \%) / 101.4 \%=13.6 \%$, an increase of $9.5 \%$. The actual increase in vote share we found in section 4 was $7.8 \%$, so it could in principle be exclusively coming from new voters. It is, however, unlikely that all of the new votes would have been cast for one party alone. For example, if only half of the new votes were for right-of-center, the resulting increase in right-ofcenter vote share would be $4.7 \%$, less than the total effect. These considerations lead us to conclude that turnout may explain part of the effect but that vote shifting is also taking place.

\section{B. Wealth}

Direct economic incentives would be the prime candidate to explain the link between ownership and voting behavior. Such incentives can arise from issues related to wealth or taxes. Recall, however, that the demutualizations did not have a direct effect on property rights, as the asset merely converted to a different legal form. Incentives for having better protection of property rights thus did not change in the conversions. Our empirical analysis also controls for possible wealth changes due to other reasons. For example, stock market participation leads to 
greater wealth accumulation over the long-term (Mehra and Prescott, 1985; Cocco, Gomes, and Maenhout, 2005).

An additional wealth-related channel factors in the issue of liquidity. Before the conversion, the asset provided a utility flow (phone service) and the owner was effectively locked in the asset, facing a high fixed cost of selling. But once phone services and ownership were decoupled, owners could sell their shares in the stock exchange for a fraction of the transaction cost they faced earlier. The ease of selling likely relaxed liquidity constraints for some households. Better liquidity might be interpreted as a cash windfall, which could change an individual's perception of her financial situation and thus alter her political behavior.

Our data allow us to construct a measure of liquidity constraints, namely, the amount of cash investors in a particular zip code withdrew from (or invested in) the stock market. Specifically, we calculate a sell-buy ratio that equals the total value of stock market sells in a zip code divided by the corresponding value for buys. We then relate this sell-buy ratio to right-of-center voting in the now familiar 2SLS framework. We replace the stock-ownership variable with the logged sellbuy ratio, collapse the data into one observation per zip code, and calculate changes in all the variables between the 1995 and 2003 elections. We add pre-treatment levels of the control variables to the regression to control for zip-code-level differences in the propensity to sell shares. For example, zip codes that were wealthier to begin with likely saw fewer withdrawals in the 1995-2003 period, even after we condition on the changes in wealth in the same period.

Table 8, Panel A, reports the first-stage results from a regression of the sell-buy ratio on the demutualization indicator and the control variables. Not surprisingly, the demutualization indicator attracts a positive and significant coefficient across all specifications. This finding implies the residents in the demutualizing towns were more likely to sell shares conditional on 
the observed covariates and changes in them: the buy-sell ratio increased by $e^{0.121}-1=12.8 \%$ in the demutualizing towns. ${ }^{10}$

Panel B relates the instrumented net cash withdrawal to changes in right-of-center vote shares. The result is a positive relation between net cash withdrawal and right-of-center vote shares, with $t$-values ranging from 0.9 and 1.4. The statistical insignificance of these effects, combined with the fact that the majority of the new shareholders did not sell their shares, suggest changes in liquid wealth did not fully drive the voting patterns. Leaving the issue of statistical significance aside, the point estimates reported in the full model (Column 5) imply a $(1+0.128)^{0.330}-1=4.1 \%$ increase in right-of-center vote share due to additional cash withdrawal in the demutualizing towns. When compared to the $7.8 \%$ total increase in right-of-center vote share, the point estimate suggests that the additional selling cannot fully explain the total effect of demutualizations on right-of-center voting.

\section{Taxes}

Besides wealth-related channels, tax issues can provide asset owners with an increased incentive to vote right-of-center. The demutualization did not cause significant changes in the taxation of cash distributions to owners: mutual companies and corporations faced the same flat corporate income tax rate and similar tax treatment of cash distributions to owners. However, the mutual form allowed customer-owners to derive untaxed benefits in the form of a customer discount on their phone bills. After ownership and phone services were decoupled in the demutualization, customers lost the discount. This loss increased the phone companies' profits, leading to increased corporate taxes. In the case of the largest of the demutualized firms

\footnotetext{
${ }^{10}$ Unreported results show the additional selling was not particularly widespread in the demutualizing towns. About $80 \%$ of the original recipients kept the shares until the end of the sample period in 2003.
} 
(Helsingin Puhelin), the customer discount had been about 60 euros per year before the conversion. The corporate tax rate at the time was $26 \%$. Losing 60 euros in tax-free benefits and gaining the same amount in pretax profits thus implies an increase of 15.60 euros $(=0.26 \times 60$ euros) in taxes paid per year. ${ }^{11}$ For the median income earner, this amount corresponds to an increase in total annual tax burden of about $0.2 \%$.

Although any increase in taxes in principle increases the incentive to vote for lower tax policies at the margin, we are skeptical about the ability of this tax effect to generate the magnitude of the change we observe in right-of-center voting. The amounts involved were small, and the chances of a single voter affecting tax policy even smaller. In expectation, the small amount and policy uncertainty likely rendered the tax benefits insignificant.

\section{Stock ownership salience}

The previous section argued that increases in wealth, and in liquid wealth in particular, are unlikely to fully explain the voting patterns around the demutualizations. The conversions did affect tax benefits, but they were likely too small and uncertain to fully explain the results. An alternative channel is stock ownership salience; that is, the demutualization induced a shift in attention.

The salience of stock ownership can work in various ways in influencing behavior. First, newly minted stockholders can start paying more attention to economic issues, increasing the weight of these issues in their voting decisions. Van Rooij, Lusardi, and Alessie (2011) show that stock market participation correlates strongly with interest in economic issues, and Bonaparte

\footnotetext{
${ }^{11}$ This calculation makes the following assumptions: the companies were operating close to breakeven profits before the demutualization effectively passing on all benefits to customer-owners; company unit sales and costs are unaffected when it starts selling at the market price; and labor supply is fixed (i.e., individuals do not increase their working hours in response to an increase in their phone bills).
} 
and Kumar (2013) report evidence showing that stockholders spend more time reading newspapers.

Second, stock ownership may induce a change in the frame of reference. A mutual company combines the roles of a customer and an owner, whereas these roles are unbundled in a demutualization. A resulting increase in the salience of ownership could shift the balance toward identifying oneself as an investor. More salient stock ownership and the changes in identity could necessitate a change in voting behavior to align actions with the new group identity. Akerlof and Kranton (2010) argue identity influences economic decisions whereas Mullainathan and Washington (2009) show how cognitive dissonance affects political attitudes. Empirical evidence suggests priming of a particular identity (such as gender, religion, ethnicity, or race) has a strong effect on decisions in many domains, including risk-taking, co-operative behavior, time preferences, and voting (see, e.g., Chen and Li, 2009; Benjamin, Choi, and Strickland, 2010; Klor and Shayo, 2010). Particularly informative in our setting is the finding in Di Tella, Galiani, and Schargrotsky (2007) that Buenos Aires squatters who were given land titles developed more individualist and materialist beliefs.

Third, salience might amplify the effect of any changes in direct economic incentives. For example, the newly minted stockholders might account for larger benefits from right-of-center policies than what would objectively seem to accrue due to property rights and tax issues. The listing of the stock could also make the financial value of the asset more visible to the owner, leading to a perceived wealth effect, even if such a wealth effect does not objectively exist.

A common thread in all these factors is that the underlying reason for changing political behavior is due to stock ownership becoming more salient. 


\section{Conclusion}

Theory and political commentary suggest ownership matters for political behavior. It can affect both the content of political beliefs and the level of political activity. Empirical evidence on the phenomenon, however, is scarce. Using a series of demutualizations as a source of plausibly exogenous variation in stock ownership, we show a positive and economically significant effect on right-of-center vote share. The institutional features, as well as our statistical methods, give confidence in that this inference is not impaired by endogeneity issues. Both the 2SLS regressions and covariate matching methods yield positive and significant estimates, and the estimates imply effect sizes of similar magnitude. The matching method that allows the inclusion of pre-treatment right-of-center vote trends and levels as additional controls is a particularly powerful remedy against potential violations of the exclusion restriction. In effect, it rules out any confounds that work through the differences in the political environment between the treatment and control towns prior to the demutualizations. These include, but are not limited to, a larger right-of-center voter base and also a pre-demutualization trend towards more right-ofcenter support that could potentially influence the town's likelihood to demutualize.

We also report somewhat weaker evidence of a positive effect on voter turnout. We consider various transmission mechanisms and show that wealth, liquidity, and tax incentives are unlikely explanations for all the patterns we observe. A potential channel that can explain the findings involves stock ownership salience: voting decisions are affected by increased attention to economic issues, and a shift in issue framing toward an investor's point of view and free-market policy, fostered by the ownership of listed stock.

That even a relatively small change in ownership can have a decisive effect on elections has interesting implications for public policy: sometimes changing people’s frame of reference can 
be easier than changing their direct incentives. This relative ease helps us understand why rightof-center politicians may use ownership as a strategic tool to attract the median voter to their party, as implied by Biais and Perotti (2002), as well as political commentary about President Bush’s Ownership Society initiative (Barnes, 2004; Nadler, 2000). The political implications of pension system and property-rights reforms are therefore potentially far-reaching. Pension systems that rely increasingly on defined contributions and individually managed retirement accounts may make equity markets more salient to voters. Sweden and Slovakia recently moved to pension systems with an option to place part of the pension contribution into a private Individual Retirement Account, and other countries are investigating similar reforms. Even greater changes in private ownership of assets are taking place in emerging markets, such as China: a 1998 reform privatized much of the housing stock, and more than 100 million stock trading accounts existed on the Chinese exchanges as of January 2009.

The general implication of this paper is that the types of financial instruments people hold can be consequential to their actions. The theory of cognitive dissonance, broadly speaking, suggests current behavior affects future attitude. The use of financial instruments can thus have other interesting feedback effects as well. For example, engaging in socially responsible investment could make investors more ethical, investing in certain consumer-product manufacturers could make investors view the firms' products more positively, and investing in a low-cost index fund could enhance a belief in market efficiency. 


\section{References}

Abadie, A., and Imbens, G. 2006, “Large Sample Properties of Matching Estimators for Average Treatment Effects”, Econometrica 74, 235-267.

Abadie, Alberto and Guido W. Imbens, 2011, “Bias-Corrected Matching Estimators for Average Treatment Effects”, Journal of Business and Economic Statistics 29, 1-11.

Akerlof, George A. and Rachel E. Kranton, 2010, "Identity Economics: How Our Identities Shape Our Work, Wages, and Well-Being,” Princeton University Press, Princeton.

Barber, Brad M. and Terrance Odean, 2012, “The Behavior of Individual Investors” in G. M. Constantinides, M. Harris, and R. M. Stulz (Eds.), Handbook in Economics and Finance, Vol. II, Elsevier, Forthcoming.

Barnes, Fred, 2004, “Realignment, Now More than Ever,” The Weekly Standard, November 22, 2004.

Benjamin, Daniel J., James J. Choi, and A. Joshua Strickland, 2010, "Social Identity and Preferences,” American Economic Review 100, 1913-1928.

Bertrand, Marianne, Esther Duflo, and Sendhil Mullainathan, 2004, "How Much Should We Trust Differences-in-Differences Estimates?” Quarterly Journal of Economics 119, 249-275.

Biais, Bruno and Enrico Perotti, 2002, “Machiavellian Privatization,” American Economic Review 92, 240-258.

Bonaparte, Yosef, and Alok Kumar, 2013, "Political activism, information costs, and stock market participation”, Journal of Financial Economics, forthcoming.

Bortolotti, Bernardo, Marcella Fantini, and Domenico Siniscalco, 2004, "Privatisation Around the World: Evidence from Panel Data,” Journal of Public Economics 88, 305-332.

Campbell, John Y., 2006, “Household Finance,” Journal of Finance 61, 1553-1604.

Chen, Yan and Sherry Xin Li, 2009, “Group Identity and Social Preferences,” American Economic Review 99, 431-457.

Cocco, João, Francisco Gomes, and Pascal Maenhout, 2005, “Consumption and Portfolio Choice over the Life-cycle,” Review of Financial Studies 18, 490-533. 
Curcuru, Stephanie, John Heaton, Deborah Lucas, and Damien Moore, 2010. "Heterogeneity and Portfolio Choice: Theory and Evidence,” in: Ait-Sahalia, Y. Hansen, L.P. (Eds.), Handbook of Financial Econometrics, Vol. I, North-Holland, Amsterdam, 337-382.

DellaVigna, Stefano and Ethan Kaplan, 2007, “The Fox News Effect: Media Bias and Voting,” Quarterly Journal of Economics 122, 1187-1234.

Dietz, Robert D. and Donald R. Haurin, 2003, "The Social and Private Micro-Level Consequences of Homeownership,” Journal of Urban Economics 54, 401-450.

DiPasquale, Denise and Edward L. Glaeser, 1999, "Incentives and Social Capital: Are Homeowners Better Citizens?” Journal of Urban Economics 45, 354-384.

Di Tella, Rafael, Sebastian Galiani, and Ernesto Schargrodsky, 2007, “The Formation of Beliefs: Evidence from the Allocation of Land Titles to Squatters,” Quarterly Journal of Economics 122, 209-241.

Edwards, George C., III, William Mitchell, and Reed Welch, 1995, "Explaining Presidential Approval: The Significance of Issue Salience,” American Journal of Political Science 39, 108-134.

Engels, Friedrich, 1873, “Zur Wohnungsfrage,” Hottingen, Zürich.

Erhemjamts, Otgo and J. Tyler Leverty, 2010, “Demise of the Mutual Organizational Form: An Investigation of the Life Insurance Industry,” Journal of Money, Credit, and Banking, 42, 1011-1036.

Faccio, Mara, 2006, “Politically Connected Firms,” American Economic Review 96, 369-386.

Fama, Eugene F. and Michael C. Jensen, 1983, “Separation of Ownership and Control,” Journal of Law and Economics 26, 301-325.

Grinblatt, Mark and Matti Keloharju, 2000, "The Investment Behavior and Performance of Various Investor Types: A Study of Finland's Unique Data Set,” Journal of Financial Economics 55, 43-67.

Goidel, Robert K., Todd G. Shields, and Mark Peffley, 1997, "Priming Theory and RAS models: Towards an Integrated Perspective of Media Influence,” American Politics Quarterly 25, 287-313. 
Guiso, Luigi, Michael Haliassos, and Tullio Jappelli (Eds.), 2003, Household Portfolios, MIT Press, Boston.

Heckman, James J., Hidehiko Ichimura, Petra E. Todd, 1997, "Matching As An Econometric Evaluation Estimator: Evidence from Evaluating a Job Training Programme," Review of Economic Studies 64, 605-654.

Heckman, James J., Hidehiko Ichimura, Petra E. Todd, 1998, "Matching As an Econometric Evaluation Estimator," Review of Economic Studies 65, 261-294.

Hix, Simon and Christopher Lord, 1997, Political Parties in the European Union. Macmillan Press, London.

Hong, Harrison and Leonard Kostovetsky, 2012, "Red and Blue Investing: Values and Finance,” Journal of Financial Economics 103, 1-19.

Imbens, Guido W. and Jeffrey M. Wooldridge, 2009. "Recent Development in the Econometrics of Program Evaluation”, Journal of Economic Literature 47, 5-86.

Iyengar, Shanto and Donald R. Kinder, 1987, News That Matters: Television and American Opinion, Chicago: University of Chicago Press.

Jones, Steven L., William L. Megginson, Robert C. Nash, and Jeffry M. Netter, 1999, "Share Issue Privatization as Financial Means to Political and Economic Ends," Journal of Financial Economics 53, 217-253.

Kaustia, Markku and Sami Torstila, 2011, "Stock Market Aversion? Political Preferences and Stock Market Participation,” Journal of Financial Economics 100, 98-112.

Kaustia, Markku and Samuli Knüpfer, 2012, "Peer Performance and Stock Market Entry,” Journal of Financial Economics 104, 321-338.

Keloharju, Matti, Samuli Knüpfer, and Sami Torstila, 2008, "Do Retail Incentives Work in Privatizations?” Review of Financial Studies 21, 2061-2095.

Klor, Esteban F. and Moses Shayo, 2010, “Social Identity and Preferences over Redistribution,” Journal of Public Economics 94, 269-278.

Lamm-Tennant, Joan and Laura T. Starks, 1993, "Stock versus Mutual Ownership Structures: The Risk Implications,” Journal of Business 66, 29-46. 
Mayers, David and Clifford W. Smith, Jr., 1986, “Ownership Structure and Control: The Mutualization of Stock Life Insurance Companies,” Journal of Financial Economics 16, 7398.

McCombs, Maxwell E. and Donald L. Shaw, 1972, “The Agenda-Setting Function of Mass Media,” Public Opinion Quarterly 36, 176-187.

Mehra, Rajnish, and Edward C. Prescott, 1985, “The Equity Premium - A Puzzle,” Journal of Monetary Economics 15, 145-161.

Mullainathan, Sendhil, 2002, “A Memory-Based Model of Bounded Rationality,” Quarterly Journal of Economics 117, 735-774.

Mullainathan, Sendhil, Joshua Schwartzstein, and Andrei Shleifer, 2008, "Coarse Thinking and Persuasion”, Quarterly Journal of Economics 123, 577-619.

Mullainathan, Sendhil and Ebonya Washington, 2009, "Sticking with Your Vote: Cognitive Dissonance and Political Attitudes,” American Economic Journal: Applied Economics 1, 86111.

Nadler, Richard, 2000, "Portfolio Politics: Nudging the Investor Class Forward,” National Review 52, 38-40.

Nurmi, Hannu J. and Lasse Nurmi, 2004. “The Parliamentary Election in Finland, March 2003”, Electoral Studies 23, 557-565.

Pagano, Marco and Paolo F. Volpin, 2005, “The Political Economy of Corporate Governance,” American Economic Review 95, 1005-1030.

Pagano, Marco and Paolo F. Volpin, 2006, “Shareholder Protection, Stock Market Development, and Politics,” Journal of the European Economic Association 4, 315-341.

Perotti, Enrico and Ernst-Ludwig von Thadden, 2006, “The Political Economy of Corporate Control and Labor Rents,” Journal of Political Economy 114, 145-174.

Rubin, Donald B., 1980, “Bias Reduction Using Mahalanobis-Metric Matching”, Biometrics 36, 293-298.

Traflet, Janice, 2003, “'Own Your Share of American Business’: Public Relations at the NYSE During the Cold War,” Business and Economic History On-line 1. 
van Rooij, Maarten, Annamaria Lusardi, and Rob Alessie, 2011, "Financial literacy and stock market participation”, Journal of Financial Economics 101, 449-472.

Weaver, David H., Maxwell E. McCombs, and Donald L. Shaw, 2004, "Agenda-Setting Research: Issues, Attributes, and Influences,” in L. L. Kaid (ed.), Handbook of Political Communication Research, Mahwah, NJ: Erlbaum.

Zhao, Zhong, 2004, "Using Matching to Estimate Treatment Effects: Data Requirements, Matching Metrics, and Monte Carlo Evidence,” Review of Economics and Statistics 86, 91107. 
Table 1

\section{Descriptive statistics}

The data include vote shares, share-ownership rates, and control variables at the zip-code level. Statistics in panels A and B are calculated over all the parliamentary elections in 1995, 1999, and 2003. The right-of-center, left-of-center, and center vote shares are defined as the share of votes cast for the National Coalition Party, the Social Democrat Party plus the Left Coalition Party, and the Center Party, respectively. In addition to these four parties, the largest parties' vote share includes the Green League and the Swedish People's Party. Voter turnout is the number of voters divided by the voting-aged (over 18 years) population. Share ownership is the number of shareholders divided by the number of inhabitants. Treated towns are municipalities that belong to the operating areas of the three demutualized telecom companies. Wealth and income are calculated as averages across households in a zip code and are measured in thousand euros. College degrees equals the share of inhabitants with a college degree. Unemployment is the share of inhabitants who are unemployed at the end of the year. Home owners is the share of owner-occupied dwellings in the area. Population density is the number of inhabitants divided by the area of the zip code and is measured in thousand inhabitants per $\mathrm{km}^{2}$. Females is the share of the female population. Panel C reports regressions of the demutualization indicator against town characteristics where the unit of observation is a town in the year 1995 (prior to any demutualizations). The two left-most columns report coefficients from a linear probability model whereas the remaining columns in the panel reports logit marginal effects evaluated at the means of all the explanatory variables. The $t$-statistics in parentheses are adjusted for heteroskedasticity.

\begin{tabular}{|c|c|c|c|c|c|c|c|}
\hline \multicolumn{8}{|c|}{ Panel A: Treated towns $(n$ of zip codes $=376)$} \\
\hline & Mean & Sd & Min & p25 & Median & p75 & Max \\
\hline Right-of-center vote share & 22.24 & 8.61 & 1.79 & 16.07 & 21.43 & 27.84 & 55.95 \\
\hline Left-of-center vote share & 33.29 & 10.39 & 5.86 & 25.65 & 33.89 & 40.06 & 67.86 \\
\hline Center vote share & 14.59 & 12.32 & 0.00 & 6.09 & 9.35 & 19.00 & 63.27 \\
\hline Largest parties vote share & 88.42 & 3.60 & 67.01 & 86.04 & 88.59 & 90.98 & 102.22 \\
\hline Voter turnout & 45.10 & 6.91 & 22.21 & 41.10 & 45.38 & 49.57 & 67.97 \\
\hline Share-ownership rate & 19.54 & 9.64 & 1.28 & 11.56 & 18.98 & 26.07 & 50.06 \\
\hline Wealth & 57.08 & 42.61 & 8.93 & 35.85 & 47.21 & 62.34 & 419.42 \\
\hline Income & 16.74 & 3.92 & 7.50 & 13.89 & 16.57 & 19.53 & 32.36 \\
\hline College degrees & 10.25 & 6.79 & 0.34 & 5.44 & 8.61 & 13.26 & 36.44 \\
\hline Unemployment & 6.35 & 3.22 & 0.58 & 3.65 & 5.94 & 8.42 & 18.03 \\
\hline Home ownership & 27.86 & 6.70 & 0.13 & 25.21 & 29.11 & 32.22 & 44.58 \\
\hline Population density & 1.29 & 2.18 & 0.00 & 0.03 & 0.38 & 1.68 & 23.50 \\
\hline Females & 50.88 & 2.97 & 36.14 & 49.03 & 50.65 & 52.32 & 62.95 \\
\hline \multicolumn{8}{|c|}{ Panel B: Control towns ( $n$ of zip codes $=2,082$ ) } \\
\hline & Mean & $\mathrm{Sd}$ & Min & p25 & Median & p75 & Max \\
\hline Right-of-center vote share & 12.72 & 8.93 & 0.14 & 5.40 & 10.92 & 18.59 & 64.19 \\
\hline Left-of-center vote share & 29.13 & 14.90 & 0.00 & 17.79 & 28.55 & 39.13 & 89.21 \\
\hline Center vote share & 40.45 & 22.33 & 0.00 & 22.07 & 42.04 & 58.33 & 92.86 \\
\hline Largest parties vote share & 90.73 & 6.01 & 37.91 & 88.41 & 91.78 & 94.44 & 103.57 \\
\hline Voter turnout & 39.71 & 10.65 & 0.00 & 32.53 & 39.13 & 45.65 & 155.80 \\
\hline Share-ownership rate & 7.86 & 4.09 & 0.55 & 5.00 & 7.23 & 9.89 & 63.14 \\
\hline Wealth & 45.25 & 17.41 & 10.31 & 32.75 & 41.70 & 53.85 & 162.42 \\
\hline Income & 12.01 & 3.00 & 6.27 & 9.68 & 11.55 & 13.94 & 23.46 \\
\hline College degrees & 3.91 & 2.84 & 0.16 & 1.94 & 3.28 & 5.09 & 25.00 \\
\hline Unemployment & 8.18 & 3.48 & 0.00 & 5.71 & 7.75 & 10.17 & 40.00 \\
\hline Home ownership & 32.10 & 5.26 & 0.24 & 29.26 & 32.37 & 35.22 & 63.17 \\
\hline Population density & 0.14 & 0.46 & 0.00 & 0.00 & 0.01 & 0.03 & 5.95 \\
\hline Females & 48.71 & 2.90 & 35.96 & 46.97 & 48.96 & 50.52 & 60.80 \\
\hline
\end{tabular}


Panel C: Regressions of demutualization indicator

\begin{tabular}{lcc}
\hline Dependent variable & \multicolumn{2}{c}{ Demutualization indicator } \\
\hline Reporting & 1 & 2 \\
\hline Specification & 0.183 & 0.157 \\
\hline Wealth & $(6.50)$ & $(5.86)$ \\
& 0.095 & 0.122 \\
Income & $(1.38)$ & $(1.80)$ \\
& 0.074 & 0.072 \\
College degrees & $(4.57)$ & $(4.77)$ \\
& 0.023 & 0.026 \\
Unemployment & $(0.70)$ & $(0.74)$ \\
& -0.072 & -0.052 \\
Home ownership & $(-1.88)$ & $(-1.65)$ \\
& 0.021 & 0.012 \\
Population density & $(4.48)$ & $(2.51)$ \\
& -0.146 & -0.188 \\
Females & $(-0.82)$ & $(-1.04)$ \\
Pre-treatment right-of-center vote level & & -0.170 \\
& & $(-9.06)$ \\
Pre-treatment right-of-center vote trend & & 0.054 \\
& & $(4.41)$ \\
Age controls & & Yes \\
Pseudo- $R^{2}$ & & \\
Number of observations & & 0.428 \\
\end{tabular}


Table 2

First stage - Effect of demutualizations on share ownership

The table reports results of OLS regressions that explain the share-ownership rate at the time of the 1995 and 2003 elections. The dependent variable is defined as the log of the share-ownership rate, i.e., the number of shareholders divided by the number of inhabitants. The demutualization dummy takes the value of one if the town has fully undergone the conversion of its local telecom firm to a publicly listed company at the time of the election. The regressions take the natural logarithm of all continuous control variables and the coefficients can thus be interpreted directly as elasticities. Control variables are as defined in Table 1 . The regressions in columns 2 through 5 also include age controls that calculate the share of inhabitants in 10-year intervals. Columns 4 and 5 break down the explanatory variables from columns 2 and 3, respectively, into 10 decile dummies (1 omitted). The $F$-statistic is for the null that the instrument does not add to the first stage model. The $t$-statistics in parentheses are adjusted for heteroskedasticity and clustering at the zip-code level.

\begin{tabular}{|c|c|c|c|c|c|}
\hline \multirow{3}{*}{$\begin{array}{l}\text { Dependent variable } \\
\text { Specification }\end{array}$} & \multicolumn{5}{|c|}{ Share ownership } \\
\hline & \multicolumn{5}{|c|}{ OLS } \\
\hline & 1 & 2 & 3 & 4 & 5 \\
\hline \multirow[t]{2}{*}{ Demutualization dummy } & 0.396 & 0.500 & 0.528 & 0.529 & 0.538 \\
\hline & $(22.07)$ & $(25.86)$ & $(27.18)$ & $(25.77)$ & (26.37) \\
\hline \multirow[t]{2}{*}{ Wealth } & & 0.321 & 0.261 & & \\
\hline & & (6.93) & $(5.68)$ & & \\
\hline \multirow[t]{2}{*}{ Income } & & 0.083 & -0.020 & & \\
\hline & & $(0.91)$ & $(-0.21)$ & & \\
\hline \multirow[t]{2}{*}{ College degrees } & & 0.039 & 0.029 & & \\
\hline & & $(2.12)$ & $(1.56)$ & & \\
\hline \multirow[t]{2}{*}{ Unemployment } & & 0.007 & -0.010 & & \\
\hline & & $(0.30)$ & $(-0.41)$ & & \\
\hline \multirow[t]{2}{*}{ Home ownership } & & & 0.552 & & \\
\hline & & & $(4.82)$ & & \\
\hline \multirow[t]{2}{*}{ Population density } & & & -0.066 & & \\
\hline & & & $(-2.09)$ & & \\
\hline \multirow[t]{2}{*}{ Females } & & & -0.285 & & \\
\hline & & & $(-1.37)$ & & \\
\hline Zip-code fixed effects & Yes & Yes & Yes & Yes & Yes \\
\hline Election fixed effects & Yes & Yes & Yes & Yes & Yes \\
\hline Age controls & No & Yes & Yes & Yes & Yes \\
\hline Decile dummies 1 & No & No & No & Yes & Yes \\
\hline Decile dummies 2 & No & No & No & No & Yes \\
\hline$F$-statistic for instrument & 470.4 & 675.8 & 757.6 & 669.4 & 699.9 \\
\hline Overall $R^{2}$ & 0.177 & 0.309 & 0.415 & 0.247 & 0.148 \\
\hline Number of observations & 4,596 & 4,596 & 4,596 & 4,596 & 4,596 \\
\hline
\end{tabular}


Table 3

\section{Second stage - Effect of share ownership on voting}

The table reports results of two-stage least squares (2SLS) regressions that explain the vote share of the right-ofcenter National Coalition party in the 1995 and 2003 elections. The 2SLS procedure in Panel A instruments share ownership by using the regressions in Table 2 as the first stage. Panel B reports the corresponding OLS estimates. The regressions take the natural logarithm of all continuous variables (both the dependent and the independent variables) and the coefficients can thus be interpreted directly as elasticities. Control variables are as defined in Table 1 . The regressions in columns 2 through 5 also include age controls that calculate the share of inhabitants in 10 -year intervals. Columns 4 and 5 break down the explanatory variables from columns 2 and 3, respectively, into 10 decile dummies (1 omitted). The $t$-statistics in parentheses are adjusted for heteroskedasticity and clustering at the zip-code level.

\begin{tabular}{|c|c|c|c|c|c|}
\hline \multicolumn{6}{|c|}{ Panel A: 2SLS regressions } \\
\hline Dependent variable & \multicolumn{5}{|c|}{ Right-of-center vote share } \\
\hline Specification & 1 & 2 & 3 & 4 & 5 \\
\hline Share ownership & $\begin{array}{c}0.324 \\
(4.32)\end{array}$ & $\begin{array}{c}0.210 \\
(3.21)\end{array}$ & $\begin{array}{c}0.190 \\
(3.03)\end{array}$ & $\begin{array}{r}0.150 \\
(2.22)\end{array}$ & $\begin{array}{c}0.139 \\
(2.09)\end{array}$ \\
\hline Wealth & & $\begin{array}{c}0.135 \\
(2.11)\end{array}$ & $\begin{array}{c}0.161 \\
(2.51)\end{array}$ & & \\
\hline Income & & $\begin{array}{r}0.355 \\
(2.51)\end{array}$ & $\begin{array}{c}0.406 \\
(2.83)\end{array}$ & & \\
\hline College degrees & & $\begin{array}{l}-0.002 \\
(-0.09)\end{array}$ & $\begin{array}{r}0.001 \\
(0.02)\end{array}$ & & \\
\hline Unemployment & & $\begin{array}{l}-0.080 \\
(-2.25)\end{array}$ & $\begin{array}{l}-0.073 \\
(-2.04)\end{array}$ & & \\
\hline Home ownership & & & $\begin{array}{l}-0.199 \\
(-1.54)\end{array}$ & & \\
\hline Population density & & & $\begin{array}{l}-0.007 \\
(-0.22)\end{array}$ & & \\
\hline Females & & & $\begin{array}{r}0.440 \\
(1.40)\end{array}$ & & \\
\hline Zip-code fixed effects & Yes & Yes & Yes & Yes & Yes \\
\hline Election fixed effects & Yes & Yes & Yes & Yes & Yes \\
\hline Age controls & No & Yes & Yes & Yes & Yes \\
\hline Decile dummies 1 & No & No & No & Yes & Yes \\
\hline Decile dummies 2 & No & No & No & No & Yes \\
\hline Overall $R^{2}$ & 0.180 & 0.266 & 0.274 & 0.239 & 0.132 \\
\hline Number of observations & 4,596 & 4,596 & 4,596 & 4,596 & 4,596 \\
\hline \multicolumn{6}{|c|}{ Panel B: OLS regressions } \\
\hline Dependent variable & & & enter vot & & \\
\hline Specification & 1 & 2 & 3 & 4 & 5 \\
\hline Share ownership & $\begin{array}{c}0.129 \\
(4.50)\end{array}$ & $\begin{array}{c}0.103 \\
(3.43)\end{array}$ & $\begin{array}{r}0.106 \\
(3.52)\end{array}$ & $\begin{array}{l}0.087 \\
(2.75)\end{array}$ & $\begin{array}{l}0.091 \\
(2.84)\end{array}$ \\
\hline Overall $R^{2}$ & 0.173 & 0.251 & 0.253 & 0.218 & 0.104 \\
\hline Number of observations & 4,596 & 4,596 & 4,596 & 4,596 & 4,596 \\
\hline
\end{tabular}


Table 4

\section{Matching estimators}

The table shows the influence of share ownership on right-of-center voting using estimators that match the treated areas to a control sample based on the nearest-neighbor method developed in Abadie and Imbens (2006). Right-ofcenter voting is measured as the change in the logged right-of-center vote share from 1995 to 2003 and covariates used in matching are the same as the control variables in Table 3 (wealth, income, college degrees, homeowners, population density, and age composition), broken down into decile dummies. In addition, the analysis uses the level of the logged right-of-center vote share in 1995 and the change in the logged right-of-center vote share from 1991 to 1995 to match the treatment towns to the nearest neighbors. All the variables are measured as of 1995 before the demutualizations took place. Panels A through D consider matching based on 1, 2, 4, and 6 nearest neighbors, respectively. Specifications 1 and 2 use the matching metric based on the inverse-of-the-variances distance (Abadie and Imbens, 2006) and the Mahalanobis distance (Rubin, 1980). Specification 3 applies the bias correction to account for the discrepancy in observables of the treatment and control towns from Abadie and Imbens (2011).

\begin{tabular}{|c|c|c|c|c|c|c|}
\hline & \multicolumn{3}{|c|}{ Panel A: Number of matches $=1$} & \multicolumn{3}{|c|}{ Panel B: Number of matches = 2} \\
\hline & $\begin{array}{l}\text { Inverse- } \\
\text { of- } \\
\text { variances } \\
\text { metric } \\
\end{array}$ & $\begin{array}{l}\text { Mahalanobis } \\
\text { metric }\end{array}$ & $\begin{array}{c}\text { Bias } \\
\text { correction } \\
\text { for match } \\
\text { discrepancy } \\
\end{array}$ & $\begin{array}{l}\text { Inverse- } \\
\text { of- } \\
\text { variances } \\
\text { metric } \\
\end{array}$ & $\begin{array}{l}\text { Mahalanobis } \\
\text { metric }\end{array}$ & $\begin{array}{c}\text { Bias } \\
\text { correction } \\
\text { for match } \\
\text { discrepancy }\end{array}$ \\
\hline & 1 & 2 & 3 & 1 & 2 & 3 \\
\hline Treatment effect & 0.121 & 0.119 & 0.124 & 0.120 & 0.118 & 0.123 \\
\hline$z$-value & (3.49) & (3.66) & (3.64) & (3.98) & (3.98) & (4.49) \\
\hline \multirow[t]{4}{*}{ Number of observations } & 2,328 & 2,328 & 2,328 & 2,328 & 2,328 & 2,328 \\
\hline & \multicolumn{3}{|c|}{ Panel C: Number of matches $=4$} & \multicolumn{3}{|c|}{ Panel D: Number of matches $=6$} \\
\hline & $\begin{array}{c}\text { Inverse-of- } \\
\text { variances } \\
\text { metric }\end{array}$ & $\begin{array}{c}\text { Mahalanobis } \\
\text { metric }\end{array}$ & $\begin{array}{c}\text { Bias } \\
\text { correction } \\
\text { for match } \\
\text { discrepancy }\end{array}$ & $\begin{array}{l}\text { Inverse- } \\
\text { of- } \\
\text { variances } \\
\text { metric } \\
\end{array}$ & $\begin{array}{c}\text { Mahalanobis } \\
\text { metric }\end{array}$ & $\begin{array}{c}\text { Bias } \\
\text { correction } \\
\text { for match } \\
\text { discrepancy }\end{array}$ \\
\hline & 1 & 2 & 3 & 1 & 2 & 3 \\
\hline Treatment effect & 0.123 & 0.119 & 0.092 & 0.122 & 0.127 & 0.105 \\
\hline$z$-value & $(4.55)$ & $(4.75)$ & $(3.90)$ & $(4.65)$ & $(5.40)$ & $(4.57)$ \\
\hline Number of observations & 2,328 & 2,328 & 2,328 & 2,328 & 2,328 & 2,328 \\
\hline
\end{tabular}


Table 5

\section{Alternative vote-share specifications}

The table reports results from alternative specifications that vary the definition of the dependent variable. Otherwise the models are identical to the 2SLS regression from the corresponding columns in Panel A of Table 3. Panel A in this table uses the vote share of the Center Party, whereas Panel B aggregates the Center Party and National Coalition vote shares. Panel C measures the left-of-center share that aggregates the votes cast for the Social Democrat Party and the Left Coalition Party. Panels D and E scale the votes cast for the Center Party and National Coalition with the votes cast for the six parties that have repeatedly appeared on the list of the largest parties. In addition to the National Coalition, Center Party, Social Democrat, and Left Coalition parties, the largest parties' vote share includes the Green League and the Swedish People's Party. The $t$-statistics in parentheses are adjusted for heteroskedasticity and clustering at the zip-code level.

\begin{tabular}{|c|c|c|c|c|c|}
\hline \multirow[t]{2}{*}{ Specification } & \multicolumn{5}{|c|}{ 2SLS } \\
\hline & 1 & 2 & 3 & 4 & 5 \\
\hline \multicolumn{6}{|c|}{ Panel A: Dep var = Center Party vote share } \\
\hline $\begin{array}{l}\text { Coefficient } \\
t \text {-value }\end{array}$ & $\begin{array}{r}0.946 \\
(12.94)\end{array}$ & $\begin{array}{r}0.604 \\
(12.11)\end{array}$ & $\begin{array}{r}0.557 \\
(12.01)\end{array}$ & $\begin{array}{r}0.336 \\
(7.85)\end{array}$ & $\begin{array}{l}0.331 \\
(7.88)\end{array}$ \\
\hline Overall $R^{2}$ & 0.136 & 0.004 & 0.047 & 0.010 & 0.025 \\
\hline Number of observations & 4,776 & 4,776 & 4,776 & 4,776 & 4,776 \\
\hline \multicolumn{6}{|c|}{ Panel B: Dep var = Center Party and National Coalition vote share } \\
\hline $\begin{array}{l}\text { Coefficient } \\
t \text {-value }\end{array}$ & $\begin{array}{r}0.368 \\
(10.07)\end{array}$ & $\begin{array}{l}0.265 \\
(9.10)\end{array}$ & $\begin{array}{l}0.247 \\
(8.96)\end{array}$ & $\begin{array}{l}0.165 \\
(5.92)\end{array}$ & $\begin{array}{r}0.163 \\
(5.96)\end{array}$ \\
\hline $\begin{array}{l}\text { Overall } R^{2} \\
\text { Number of observations }\end{array}$ & $\begin{array}{l}0.029 \\
4,785\end{array}$ & $\begin{array}{l}0.000 \\
4,785\end{array}$ & $\begin{array}{l}0.051 \\
4,785\end{array}$ & $\begin{array}{r}0.0002 \\
4,785\end{array}$ & $\begin{array}{l}0.002 \\
4,785\end{array}$ \\
\hline \multicolumn{6}{|c|}{ Panel C: Dep var = Social Democrat and Left Coalition Party vote share } \\
\hline $\begin{array}{l}\text { Coefficient } \\
t \text {-value }\end{array}$ & $\begin{array}{l}-0.167 \\
(-3.69)\end{array}$ & $\begin{array}{l}-0.096 \\
(-2.47)\end{array}$ & $\begin{array}{l}-0.081 \\
(-2.20)\end{array}$ & $\begin{array}{l}-0.074 \\
(-1.87)\end{array}$ & $\begin{array}{l}-0.077 \\
(-1.98)\end{array}$ \\
\hline Overall $R^{2}$ & 0.002 & 0.212 & 0.001 & 0.175 & 0.177 \\
\hline Number of observations & 4,770 & 4,770 & 4,770 & 4,770 & 4,770 \\
\hline \multicolumn{6}{|c|}{ Panel D: Dep var = Vote share of all right-of-center parties excluding small parties } \\
\hline $\begin{array}{l}\text { Coefficient } \\
t \text {-value }\end{array}$ & $\begin{array}{l}0.285 \\
(3.84)\end{array}$ & $\begin{array}{l}0.166 \\
(2.56)\end{array}$ & $\begin{array}{l}0.148 \\
(2.39)\end{array}$ & $\begin{array}{r}0.121 \\
(1.80)\end{array}$ & $\begin{array}{r}0.110 \\
(1.67)\end{array}$ \\
\hline Overall $R^{2}$ & 0.183 & 0.280 & 0.284 & 0.257 & 0.166 \\
\hline Number of observations & 4,596 & 4,596 & 4,596 & 4,596 & 4,596 \\
\hline \multicolumn{6}{|c|}{ Panel E: Dep var = Vote share of Center Party and National Coalition excluding small parties } \\
\hline $\begin{array}{l}\text { Coefficient } \\
t \text {-value }\end{array}$ & $\begin{array}{l}0.313 \\
(9.44)\end{array}$ & $\begin{array}{l}0.213 \\
(8.11)\end{array}$ & $\begin{array}{l}0.198 \\
(7.96)\end{array}$ & $\begin{array}{r}0.135 \\
(5.34)\end{array}$ & $\begin{array}{r}0.135 \\
(5.41)\end{array}$ \\
\hline Overall $R^{2}$ & 0.028 & 0.003 & 0.057 & 0.006 & 0.0002 \\
\hline Number of observations & 4,781 & 4,781 & 4,781 & 4,781 & 4,781 \\
\hline
\end{tabular}


Table 6

Excluding towns with no mutuals

The table reports results from an alternative specification that discards all the towns that were not served by a mutual telecom firm. The excluded towns were the operating areas of the partially government-owned Telecom Finland (later TeliaSonera). Otherwise, the models are identical to the OLS regressions in Table 2 (Panel A) and to the 2SLS regression in Table 3 (Panel B). The $t$-statistics in parentheses are adjusted for heteroskedasticity and clustering at the zip-code level.

\begin{tabular}{|c|c|c|c|c|c|}
\hline \multicolumn{6}{|c|}{ Panel A: First-stage regressions } \\
\hline \multirow{2}{*}{$\begin{array}{l}\text { Dependent variable } \\
\text { Specification }\end{array}$} & \multicolumn{5}{|c|}{ Share ownership } \\
\hline & 1 & 2 & 3 & 4 & 5 \\
\hline \multirow[t]{2}{*}{ Demutualization dummy } & 0.415 & 0.486 & 0.513 & 0.513 & 0.521 \\
\hline & $(20.98)$ & $(22.75)$ & $(24.40)$ & (21.93) & $(22.45)$ \\
\hline Overall $R^{2}$ & 0.255 & 0.465 & 0.001 & 0.428 & 0.123 \\
\hline Number of observations & 2,452 & 2,452 & 2,452 & 2,452 & 2,452 \\
\hline \multicolumn{6}{|c|}{ Panel B: Second-stage regressions } \\
\hline Dependent variable & \multicolumn{5}{|c|}{ Right-of-center vote share } \\
\hline Specification & 1 & 2 & 3 & 4 & 5 \\
\hline \multirow{2}{*}{ Share ownership } & 0.312 & 0.200 & 0.198 & 0.154 & 0.144 \\
\hline & $(4.70)$ & (3.09) & (3.19) & (2.28) & (2.17) \\
\hline \multirow[t]{2}{*}{ Wealth } & & 0.104 & 0.107 & & \\
\hline & & $(1.40)$ & (1.39) & & \\
\hline \multirow[t]{2}{*}{ Income } & & 0.230 & 0.237 & & \\
\hline & & $(1.33)$ & $(1.35)$ & & \\
\hline \multirow[t]{2}{*}{ College degrees } & & -0.039 & -0.041 & & \\
\hline & & $(-1.10)$ & $(-1.14)$ & & \\
\hline \multirow[t]{2}{*}{ Unemployment } & & -0.116 & -0.107 & & \\
\hline & & $(-2.76)$ & $(-2.50)$ & & \\
\hline \multirow[t]{2}{*}{ Home ownership } & & & 0.082 & & \\
\hline & & & $(0.57)$ & & \\
\hline \multirow[t]{2}{*}{ Population density } & & & 0.042 & & \\
\hline & & & $(0.71)$ & & \\
\hline \multirow[t]{2}{*}{ Females } & & & 0.569 & & \\
\hline & & & $(1.42)$ & & \\
\hline Zip-code fixed effects & Yes & Yes & Yes & Yes & Yes \\
\hline Election fixed effects & Yes & Yes & Yes & Yes & Yes \\
\hline Age controls & No & Yes & Yes & Yes & Yes \\
\hline Decile dummies 1 & No & No & No & Yes & Yes \\
\hline Decile dummies 2 & No & No & No & No & Yes \\
\hline Overall $R^{2}$ & 0.189 & 0.230 & 0.294 & 0.238 & 0.203 \\
\hline Number of observations & 2,452 & 2,452 & 2,452 & 2,452 & 2,452 \\
\hline
\end{tabular}


Table 7

Effect of share ownership on voter turnout

The table reports results of two-stage least squares (2SLS) regressions that explain voter turnout in the 1995 and 2003 elections. Voter turnout is defined as the number of voters divided by the voting-aged (over 18 years) population. The 2SLS procedure instruments for share ownership by using the regressions in Table 2 as the first stage. The regressions take the natural logarithm of all continuous variables and the coefficients can thus be interpreted directly as elasticities. Control variables are as defined in Table 1. The regressions also include unreported age controls that calculate the share of inhabitants in 10-year intervals. Columns 4 and 5 break down the explanatory variables from columns 2 and 3, respectively, into 10 decile dummies (1 omitted). The $t$-statistics in parentheses are adjusted for heteroskedasticity and clustering at the zip-code level.

\begin{tabular}{|c|c|c|c|c|c|}
\hline \multirow{3}{*}{$\begin{array}{l}\text { Dependent variable } \\
\text { Specification }\end{array}$} & \multicolumn{5}{|c|}{ Voter turnout } \\
\hline & \multicolumn{5}{|c|}{ 2SLS } \\
\hline & 1 & 2 & 3 & 4 & 5 \\
\hline Share ownership & $\begin{array}{l}0.075 \\
(2.54)\end{array}$ & $\begin{array}{c}0.050 \\
(1.95)\end{array}$ & $\begin{array}{c}0.057 \\
(2.30)\end{array}$ & $\begin{array}{c}0.021 \\
(0.82)\end{array}$ & $\begin{array}{l}0.025 \\
(0.99)\end{array}$ \\
\hline Wealth & & $\begin{array}{l}-0.083 \\
(-3.52)\end{array}$ & $\begin{array}{l}-0.091 \\
(-3.85)\end{array}$ & & \\
\hline Income & & $\begin{array}{l}-0.143 \\
(-2.76)\end{array}$ & $\begin{array}{l}-0.159 \\
(-3.00)\end{array}$ & & \\
\hline College degrees & & $\begin{array}{l}-0.008 \\
(-0.77)\end{array}$ & $\begin{array}{l}-0.009 \\
(-0.90)\end{array}$ & & \\
\hline Unemployment & & $\begin{array}{l}-0.001 \\
(-0.08)\end{array}$ & $\begin{array}{l}-0.003 \\
(-0.21)\end{array}$ & & \\
\hline Home ownership & & & $\begin{array}{c}0.067 \\
(1.43)\end{array}$ & & \\
\hline Population density & & & $\begin{array}{c}0.002 \\
(0.18)\end{array}$ & & \\
\hline Females & & & $\begin{array}{l}-0.108 \\
(-0.94)\end{array}$ & & \\
\hline Zip-code fixed effects & Yes & Yes & Yes & Yes & Yes \\
\hline Election fixed effects & Yes & Yes & Yes & Yes & Yes \\
\hline Age controls & No & Yes & Yes & Yes & Yes \\
\hline Decile dummies 1 & No & No & No & Yes & Yes \\
\hline Decile dummies 2 & No & No & No & No & Yes \\
\hline Overall $R^{2}$ & 0.070 & 0.011 & 0.013 & 0.030 & 0.050 \\
\hline Number of observations & 4,788 & 4,788 & 4,788 & 4,788 & 4,788 \\
\hline
\end{tabular}


Table 8

\section{Effect of liquid wealth on voting}

The table reports results of two-stage least squares (2SLS) regressions that explain the change in the logged right-ofcenter vote share from 1995 to 2003. Unit of observation is a zip code, and the dependent and control variables are measured as changes in logged values of the variables between 1995 and 2003. The regressions also include the logged values of the variables in 1995 as additional controls. Net cash is measured as the logged ratio of the total value of all sell transactions to the total value of all buy transactions in a zip code from 1995 to 2003. Panels A and $\mathrm{B}$ report the first-stage and the second-stage results, respectively. Columns 4 and 5 break down the explanatory variables from columns 2 and 3, respectively, into 10 decile dummies (1 omitted). The $t$-statistics in parentheses are adjusted for heteroskedasticity.

\begin{tabular}{|c|c|c|c|c|c|}
\hline \multicolumn{6}{|c|}{ Panel A: First-stage regressions } \\
\hline Dependent variable & \multicolumn{5}{|c|}{ Net cash withdrawals } \\
\hline Specification & 1 & 2 & 3 & 4 & 5 \\
\hline \multirow[t]{2}{*}{ Demutualization dummy } & 0.112 & 0.107 & 0.116 & 0.110 & 0.121 \\
\hline & $(3.92)$ & $(3.52)$ & (3.69) & $(3.61)$ & (3.78) \\
\hline Adjusted $R^{2}$ & 0.043 & 0.052 & 0.051 & 0.055 & 0.048 \\
\hline Number of observations & 2,230 & 2,230 & 2,230 & 2,230 & 2,230 \\
\hline \multicolumn{6}{|c|}{ Panel B: Second-stage regressions } \\
\hline Dependent variable & \multicolumn{5}{|c|}{ Right-of-center vote share } \\
\hline Specification & 1 & 2 & 3 & 4 & 5 \\
\hline \multirow[t]{2}{*}{ Net cash withdrawals } & 0.392 & 0.287 & 0.270 & 0.408 & 0.330 \\
\hline & $(1.35)$ & $(0.93)$ & $(0.90)$ & $(1.37)$ & (1.18) \\
\hline \multirow[t]{2}{*}{ Wealth } & & 0.211 & 0.206 & & \\
\hline & & $(2.18)$ & (2.13) & & \\
\hline \multirow[t]{2}{*}{ Income } & & 1.355 & 1.389 & & \\
\hline & & $(6.04)$ & (6.15) & & \\
\hline \multirow[t]{2}{*}{ College degrees } & & 0.064 & 0.065 & & \\
\hline & & $(1.33)$ & $(1.37)$ & & \\
\hline \multirow[t]{2}{*}{ Unemployment } & & -0.001 & -0.006 & & \\
\hline & & $(-0.02)$ & $(-0.09)$ & & \\
\hline \multirow[t]{2}{*}{ Home ownership } & & & -0.209 & & \\
\hline & & & $(-1.35)$ & & \\
\hline \multirow[t]{2}{*}{ Population density } & & & -0.058 & & \\
\hline & & & $(-2.12)$ & & \\
\hline \multirow[t]{2}{*}{ Females } & & & 0.104 & & \\
\hline & & & $(0.21)$ & & \\
\hline Age controls & No & Yes & Yes & Yes & Yes \\
\hline Decile dummies 1 & No & No & No & Yes & Yes \\
\hline Decile dummies 2 & No & No & No & No & Yes \\
\hline Adjusted $R^{2}$ & 0.311 & 0.352 & 0.355 & 0.326 & 0.352 \\
\hline Number of observations & 2,230 & 2,230 & 2,230 & 2,230 & 2,230 \\
\hline
\end{tabular}




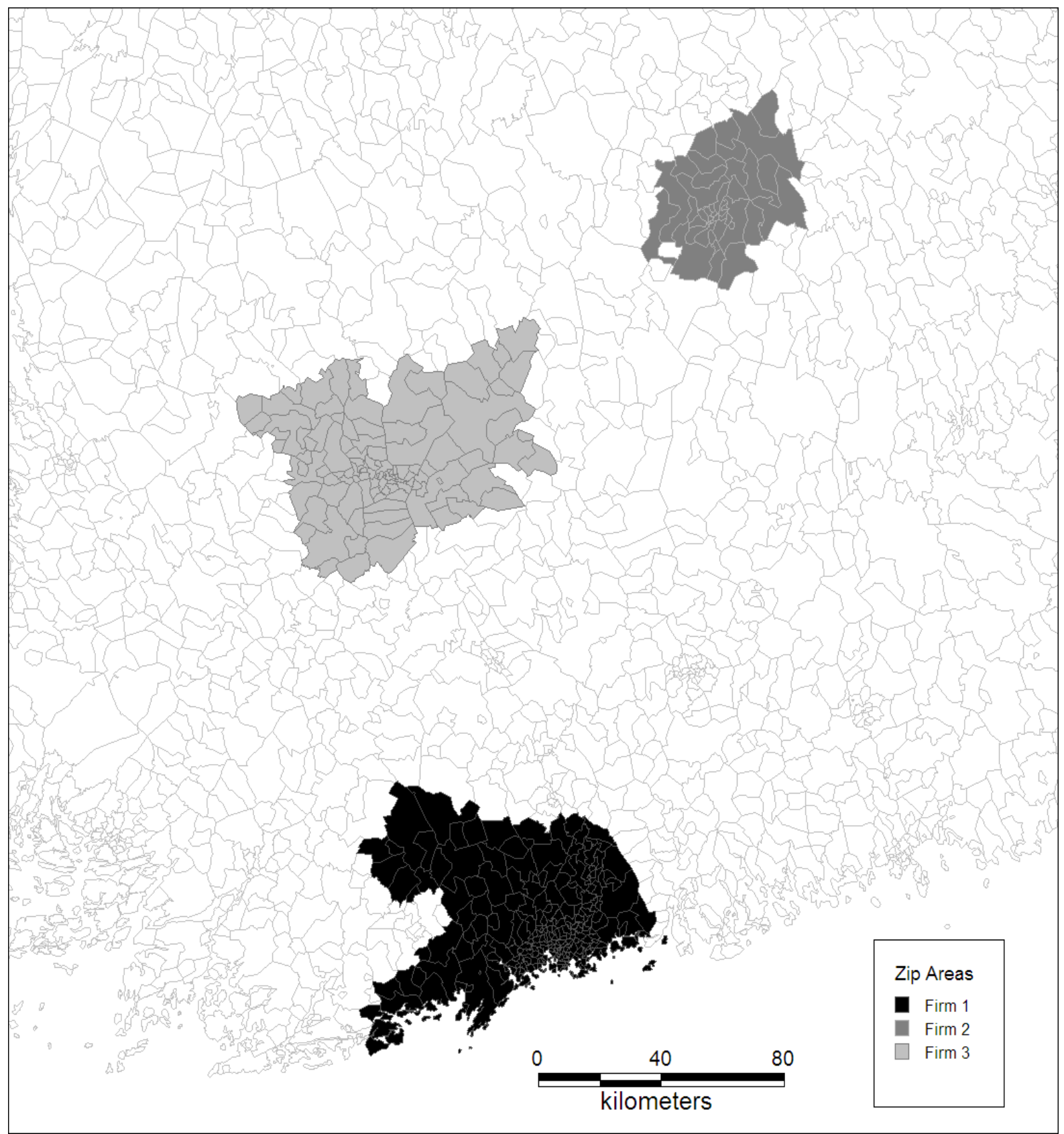

Figure 1. Treatment towns and zip codes. The map shows Southern and Central Finland by zip code. The treatment areas, that is, the zip codes in which a demutualizing telecom company had a local fixed line monopoly, are shaded. The lowest treatment area centers around the capital, Helsinki (firm 1), the northern one around the city of Jyväskylä (firm 2), and the middle one around the city of Tampere (firm 3). 
Figure 2. Share-ownership rate in treatment and control zip codes. The treatment zip codes are in towns in which the mutually owned local telecom company was converted into a publicly listed company. The control areas are all the other zip codes.

$30 \%$

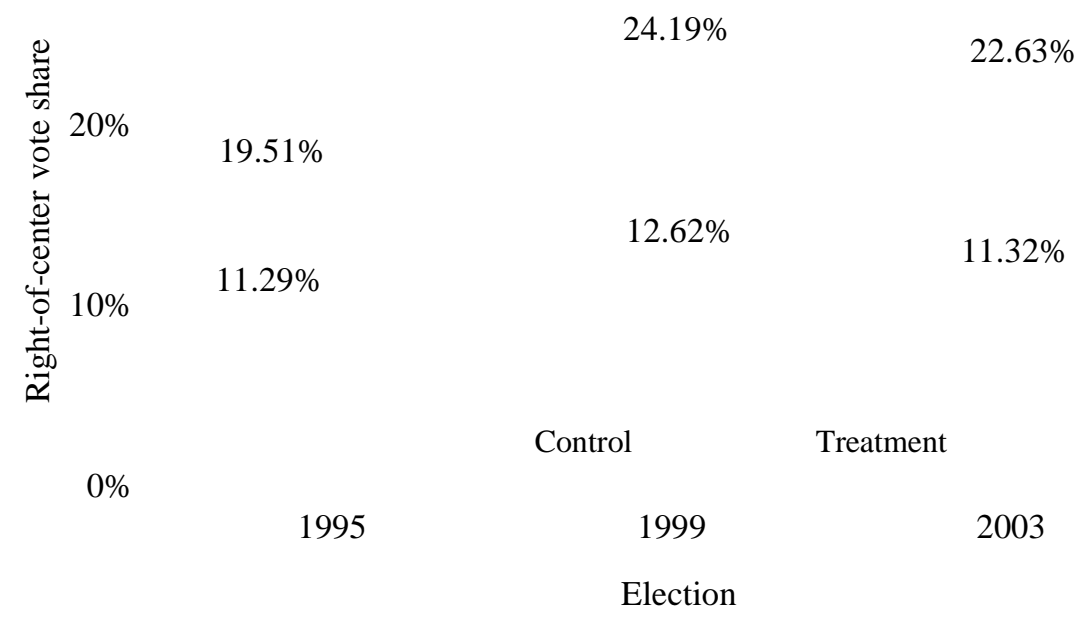

Figure 3. Right-of-center vote share in treatment and control zip codes. This figure plots the share of votes cast for the right-of-center National Coalition Party in the Finnish parliamentary elections. The treatment zip codes are in towns in which the mutually owned local telecom company was converted into a publicly listed company. The control areas are all the other zip codes. 


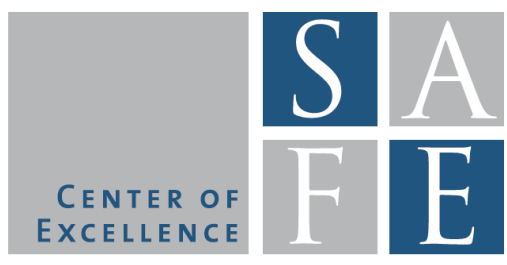

WORKING PAPER SERIES

\section{Recent Issues}

No. 1 Dimitris Georgarakos - Michalis Household Debt and Social Interaction Haliassos - Giacomo Pasini 